\title{
Sedimentary facies, depositional environments and conceptual outcrop analogue (Dam Formation, early Miocene) Eastern Arabian Platform, Saudi Arabia: a new high-resolution approach
}

\author{
Syed Haroon $\mathrm{Ali}^{1}{ }^{\circledR}$. Osman M. Abdullatif ${ }^{2} \cdot$ Lamidi O. Babalola $^{3} \cdot$ Fawwaz M. Alkhaldi ${ }^{4} \cdot$ Yasir Bashir $^{5}$. \\ S. M. Talha Qadri · Ali Wahid ${ }^{7}$
}

Received: 18 December 2020 / Accepted: 30 April 2021 / Published online: 15 May 2021

(c) The Author(s) 2021

\begin{abstract}
This paper presents the facies and depositional environment of the early Miocene Dam Formation, Eastern Arabian platform, Saudi Arabia. Deposition of Dam Formation (Fm.) was considered as a restricted shallow marine deposition. Few studies suggest the role of sea-level change in its deposition but were without decisive substantiation. Here, we describe the facies and high-resolution model of Dam Fm. under varying depositional conditions. The depositional conditions were subjected to changing relative sea level and tectonics. High-resolution outcrop photographs, sedimentological logs, and thin sections present that the mixed carbonate-siliciclastic sequence was affected by a regional tectonics. The lower part of Dam Fm. presents the development of carbonate ramp conditions that are represented by limestones and marl. The depositional conditions fluctuated with the fall of sea level, and uplift in the region pushed the siliciclastic down-dip and covered the whole platform. The subsequent rise in sea level was not as pronounced and thus allowed the deposition of microbial laminites and stromatolitic facies. The southeast outcrops, down-dip, are more carbonate prone as compared to the northwest outcrop, which allowed the deposition of siliciclastic-prone sedimentation up-dip. All facies, architecture, heterogeneity, and deposition were controlled by tectonic events including uplift, subsidence, tilting, and syn-sedimentary faulting, consequently affecting relative sea level. The resulting conceptual outcrop model would help to improve our understanding of mixed carbonate-siliciclastic systems and serve as an analogue for other stratigraphic units in the Arabian plate and region. Our results show that Dam Fm. can be a good target for exploration in the Northern Arabian Gulf.
\end{abstract}

Keywords Facies $\cdot$ Coastal environment $\cdot$ Early Miocene $\cdot$ Arabian platform $\cdot$ Tectonics $\cdot$ Sea level

Syed Haroon Ali

haroonali.geol@gmail.com

Osman M. Abdullatif

osmanabdulkfu@gmail.com

Lamidi O. Babalola

lameedbabalola@gmail.com

Fawwaz M. Alkhaldi

fawwaz658@gmail.com

Yasir Bashir

yasir.bashir@usm.my

S. M. Talha Qadri

talhaqadri_uos@hotmail.com

Ali Wahid

ali.wahid@ajku.edu.pk

1 Department of Earth Sciences, University of Sargodha,

Sargodha, Pakistan
2 Geosciences Department, College of Petroleum and Geosciences, King Fahd University of Petroleum and Minerals, Dhahran, Saudi Arabia

3 Center for Integrative Petroleum Research, King Fahd University of Petroleum and Minerals, Dhahran 31261, Saudi Arabia

4 Center for Integrative Petroleum Research, Saudi Aramco, Saudi Arabia

5 School of Physics, Universiti Sains Malaysia, Penang, Malaysia

6 Department of Earth Sciences, University of Toronto, Toronto, Canada

7 Institute of Geology, University of Azad Jammu and Kashmir, Muzaffarabad, AJK, Pakistan 


\section{Abbreviations}

Fm Formation

SEM Scanning electron microscope

EDS Energy-dispersive spectra

XRD X-Ray diffraction

\section{Introduction}

Outcrop analogues have a paramount role in comprehending subsurface reservoir heterogeneity and architecture (Bosence 2005; Roberts and Bally 2012; Warrlich et al. 2008; Asprion and Aigner 1999; Eltom et al. 2020). Analogues contribute crucial information on geometry, connectivity, and geobody size, which is otherwise challenging from seismic and well log data. The use of analogues has been acknowledged in many studies conducted by reservoir modellers (Grammer et al. 2004; Pringle et al. 2006; Enge et al. 2007; Verwer et al. 2008; Fabuel-Perez et al. 2009; Redfern et al. 2010; Qadri et al. 2017; Ghon et al. 2018; Rankey et al. 2019; Qadri et al. 2019a, b, 2020; Eltom et al. 2020; Islam et al. 2021; Qadri et al. 2021). The reconstruction of the analogue model in the spatial dimensions by closely spaced high-resolution photographs provides a new tool in conventional field studies. This new paradigm shift initiated the use of high-resolution photographs (all photographs are geo-referenced) for the onsite recording of depositional architectures and facies geometries and lets datasets, which could be conversely impossible to obtain. Large outcrops are challenging for data collection due to several factors, e.g. sand cover, discontinuities, and regional framework. Thus, the high-resolution analogue model provides continuity and connectivity of the observations based on the fieldwork dataset to fit a regional framework.

Regional tectonics and relative sea level are the controlling factors of deposition in mixing carbonate-siliciclastic sedimentation (Dolan 1989; Sanders and Pons 2001; Yang et al. 2014; Brandano 2014; Carlucci et al. 2014). Mixed carbonate-siliciclastic platforms have alternate exposure/ immersion of the basin top, resulting in lowstand siliciclastic and highstand carbonate deposition. Tectonics may influence the syn- and post-depositional conditions as fault blocks through subsidence, uplift, tilting, controlling the location and development of mixed carbonate-siliciclastic sedimentation (Moore 1989; Ziegler 2001; Wilson 2012; Cornacchia et al. 2020). Development of the mixed depositional system is a by-product of relative sea level punctuated by tectonics that allowed the carbonate facies exposure to the subsequent deposition of siliciclastics.

The sub-horizontal strata of the Dam Fm. outcrops near Al-Lidam escarpment (Abdelkarim et al. 2019) and forming flat-topped hills provide an excellent opportunity to test the high-resolution analogue model (Fig. 1). The Dam Fm. has good outcrop quality, but its outcrops are a group of widely scattered and unconnected, forty (40) isolated hills and ridges (Ali 2015). As a result of sand cover in the lower parts of the outcrops, differential erosion, and structural deformation, the complete succession of the formation is not exposed in the study locality. Barely, the middle portion of Dam Fm. is uncovered and exposed here (Fig. 1c). The 15-26.3-m-thick section of Dam Fm. outcrops in Al-Lidam area represents a photomontage arrangement of facies heterogeneity and architecture.

The rock cycles of Dam Fm. consist of mudrocks, sandstones, and limestones rock types arranged in a set of shallowing upward cycles (Alkhaldi 2009). Overall, the setting records a vertical change from the lower part as sandy limestone and marls rich in molluscs and foraminifera and becomes siliciclastic dominated in the middle. The bioturbated and channelized sandstones are overlain by stromatolitic and oolitic limestones. Red-bed facies marks the subaerial exposure of the buildup and initiation of sea-level fall.

The aims of the paper are:

1. To establish the facies and depositional environments: microscale to macroscale and to examine the heterogeneity of the sedimentary sequences of the Dam Fm.

2. To provide an outcrop analogue model with its evolution with relative sea-level changes punctuated by tectonics.

\section{Geological setting}

The impact of the Arabian Plate against the Eurasian during the Oligocene to Early Miocene periods led to the formation of the Zagros belt and consequently the termination of the Neo-Tethys ocean (Zielger 2001; Ghasemi and Talbot 2006; Farzipour-Saein et al. 2009; Mouthereau et al. 2012; Bretis et al. 2012; Ring 2014; Ajirlu et al. 2016). The dominantly carbonate foredeep basins were replaced by the influx of clastics in a continental foreland basin (Sharland and Pons 2001; Pirouz et al. 2011). The Arabian Plate was gradually tilted towards the north-north-east because of its rifting from Africa (Fig. 1b; Ziegler 2001; Stern and Johnson 2010). Subsidence in the area is interpreted to have been primarily caused by the structural loading of the Zagros thrust sheets (Sharland et al. 2004). The subsidence of the Arabian plate continued, and it caused emergent inclination of the plate owing to the structural loading of the Zagros (Alavi 2007). According to Sharland et al. (2004), a foreland bulge may have been developed along the west line of the Euphrates River. The Oligo-Miocene deposits are thickest in the foredeep and thin towards the northeastward of the Arabian foreland into a fore-bulge (Sharland et al. 2004; Patton and O' connor 1988). These deposits become thicker 
Fig. 1 a Map of the Middle East and south Asia, with inset. b Palaeofacies map of Miocene, with yellow colour indicating the distribution of Dam Fm. (modified after Ziegler 2001). c Aerial photograph showing the location of the study area (red box). d The location of outcrops studied (green circles), along with legend presenting outcrops used in previous studies (Alkhaldi 2009)

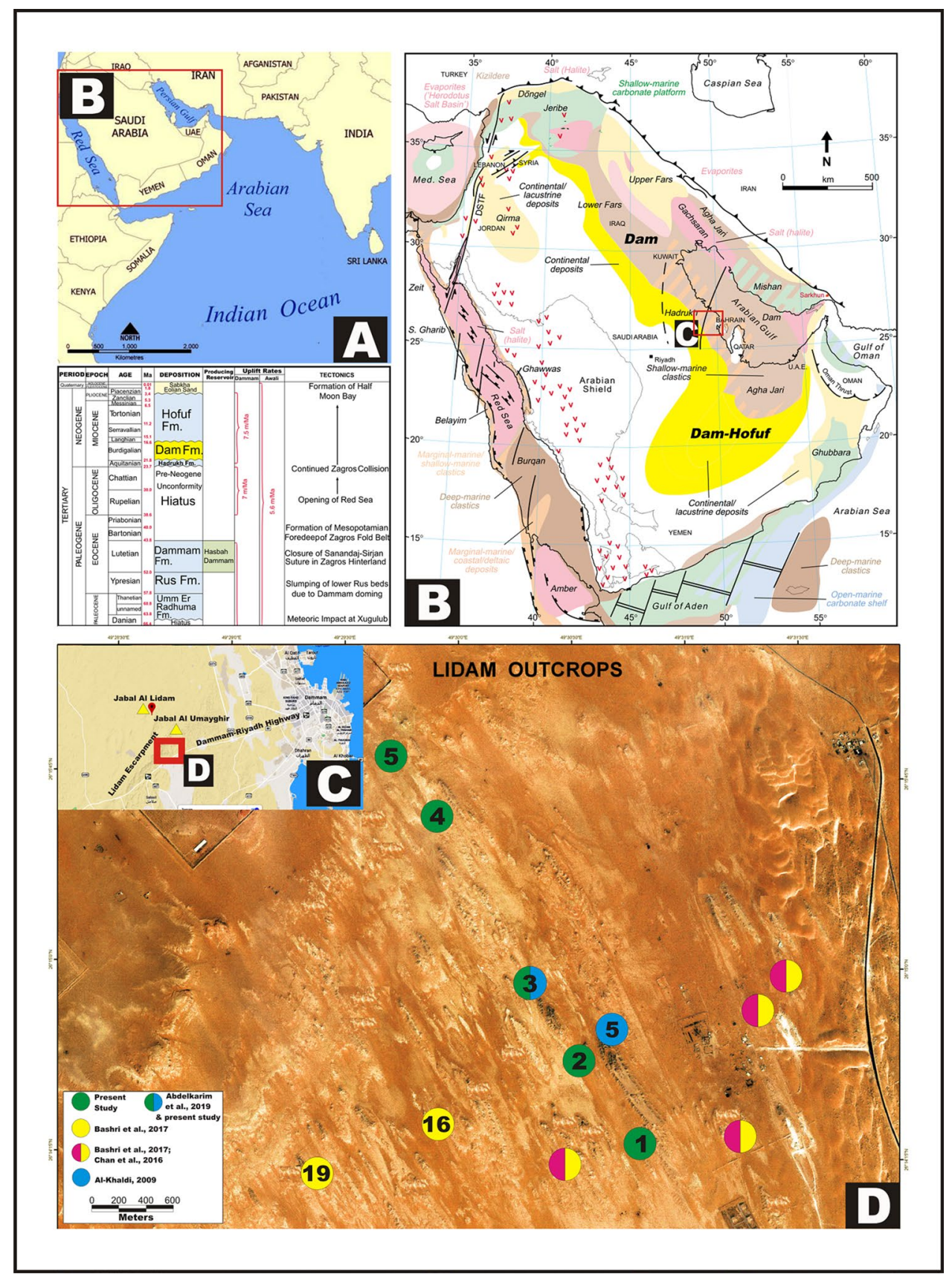

in the Eastern Margin in Saudi Arabia and make small backbulge basins (Johnson 2008). The study area of Al-Lidam is located on one of these basins (Ali and Abdullatif 2015).

Residual patches or outcrops of Dam Fm. in Eastern Saudi Arabia (Fig. 1d) indicate that the sea in the early Miocene was covering $120 \mathrm{~km}$ of the Arabian Platform from the current coastline (Fig. 1c). It concealed a wide-area parallel to the coast, from north of Ghawar to Jibal a Nu'arylyah to South of Qatar, a distance of 450 km (Tayyib 2007).

In Saudi Arabia, the Dam Fm. (Power et al. 1966) is of early Miocene in age and is saddled between two non-marine formations, the early Miocene age Hadrukh Fm. at the base and middle to late Miocene to Pliocene age Hofuf Fm. at the top (Power et al. 1966; Weijermars 1999). In the Al-Hofuf area, the contact of overlying Hofuf is placed at the occurrence of quartz pebble beds. The lower contact with Hadrukh Fm. is established at the emergence of Echinocyamus (echinoids species) bearing fossiliferous marl (Fig. 1). The middle part of Dam Fm. is outcropped close to Al-Lidam (Chan et al. 2017; Fig. 1c) area, whereas the upper section is uncovered adjacent to Al-Umayghir (Fig. 1c). 


\section{Methods and datasets}

The Dam Formation is called after the type locality Jabal Al-Lidam. The coordinates of Jabal Al-Lidam are $26^{\circ} 21^{\prime}$ $42^{\prime \prime} \mathrm{N}$ and $49^{\circ} 27^{\prime} 42^{\prime \prime} \mathrm{E}$, inside the escarpment of Al-Lidam and adjoins the Riyadh-Dammam main road, nearly $80 \mathrm{~km}$ from Dhahran city (Fig. 1). The outcrops form small ragged 10-20 m elevated detached inselbergs, continuous on NNWSSE trending platforms (Bashri et al., 2017). The escarpment exhibits well-exposed early Miocene age, Dam Fm. easily accessible outcrops (Alkhaldi 2009; Alkhaldi et al. 2014; Ali 2015; Ali et al. 2016a; Ali et al. 2016b; Ali et al. 2021a). About five outcrops were selected along the NW-SE transect, (outcrops 1, 2, 3, 4, and 5; Fig. 1d), from forty outcrops in the study area. The outcrops were sedimentologically logged in terms of facies, cyclicities, and stratigraphic stacking patterns. The 18-m-thick stratigraphic section at outcrop 3 was used as the basis for matching cyclicities and boundaries between the studied outcrops.

Sampling was done with an overall space of $30 \mathrm{~cm}$, mostly bed by bed. Two samples were taken from a thick bed to cover the base and top of the bed. Furthermore, 110 thin sections and 100 polished slabs were examined for sedimentological analysis.

For the analogue model, we utilized the high-resolution photographs of a Canon EOS 4000D Kit EF-S 18-55 III, with a flexible aluminium tripod Camera stand; all the photographs were geo-referenced using software called Picasa version 3.9. About 800 photographs were taken from each outcrop. All five outcrops were photographed in a specific strategy to maintain a lateral continuity of exposure, facies contacts, bedding orientation, sedimentary structures, and avoid any gaps in the section. The photographs were printed and contacts and facies were described in the field. Then, the interpreted photographs were imported into the CorelDRAW graphics suite, overlapped and field descriptions were digitized. The stratigraphic surfaces, facies boundaries were marked in the overlapped final image. The $2-4^{\circ} \mathrm{SE}$ dip of outcrop 3 , which is used here as a base, allowed us to construct a complete facies and outcrop analogue model.

The detailed laboratory methods include selecting samples and processing them using standard thin section preparation, XRD and SEM-EDS techniques. These techniques helped in understanding ooid, quartz, and skeletal grains especially at higher resolution along with their mineralogical composition. Thin sections were studied using an Olympus optical petrographic microscope. The photomicrographs from both thin section and SEM images were digitized and described using the JMicroVision software. The facies analysis was based on quantitative analysis (Flügel 2010) and textural features. The Dunham (1962) and Embry and
Klovan (1972) carbonate schemes were used to classifying the rock fabrics encountered in the outcrop sections.

\section{Results}

\section{Facies analysis}

Five outcrops were used for this study (Fig. 1d). The outcrops were the main control of stratigraphic understanding and architecture. The $\sim 15-26.3 \mathrm{~m}$, facies succession, shows carbonate facies at the base with various grain types, e.g. gastropods, skeletal fragments, ooids, and aggregate grains. It is followed by siliciclastic facies consisting of mudrock and sandstones. The middle section of Dam Fm. is capped by carbonate facies containing, stromatolites, ooids, thrombolites, intraclasts, peloids, and skeletal fragments (Ali et al. 2016b). Based on textures, sedimentary structures, and components, both carbonate and siliciclastic facies have been divided into 12 facies. The facies which are grouped into three facies associations and presented graphically in lithological logs (Fig. 2) are described in the following section.

\section{Carbonate facies}

Stromatolitic boundstone Description This facies was previously described as a carbonate laminite/stromatolites (Alkhaldi 2009), stromatolitic limestone (Chan et al. 2017), stromatolites (Bashri et al., 2017), and stromatolitic boundstone (Abdelkarim et al. 2019). The facies overlies a massive foraminiferal pack-grainstone facies and occurs in two cycles in outcrop 4 . While in outcrop 2, it covers the laminated oolitic grainstone, and in outcrop 3 it forms the base of the escarpment-forming sequence. Facies thickness varies from 0.5 to $1.5 \mathrm{~m}$ (Fig. 3). Stromatolites dominant bottom and middle parts of the Dam Fm., in southern and northern outcrops, respectively, as seen in Fig. 2. They exist on the upper part of the laminated ooid grainstone and form a 50- to 80-cm-thickness unit. The stromatolites shape detached columnar structures ranging from 3 to $20 \mathrm{~cm}$ in height. The upper part of the structure consists of branching digitate stromatolites. They are $10-20 \mathrm{~cm}$ in diameter, $4 \mathrm{~cm}$ thick, and $10 \mathrm{~cm}$ in height which is present in the medium to thick beds. Stromatolites become more digitate upward. The stromatolites commonly nucleate around intraclasts and scoured surfaces. In a cross-sectional view, they are circular to elliptical with adjacent columns showing lateral linked stromatolites. The tops and shoulders are rounded and sides taper towards the base of the beds (Fig. 3). The surface texture of the stromatolitic pillars is smooth; made up of fine laminae consisting of fenestra or small pores. Oolitic grainstones overlie the stromatolites and fill the gaps between isolated stromatolites. The laminated oolitic grainstones 


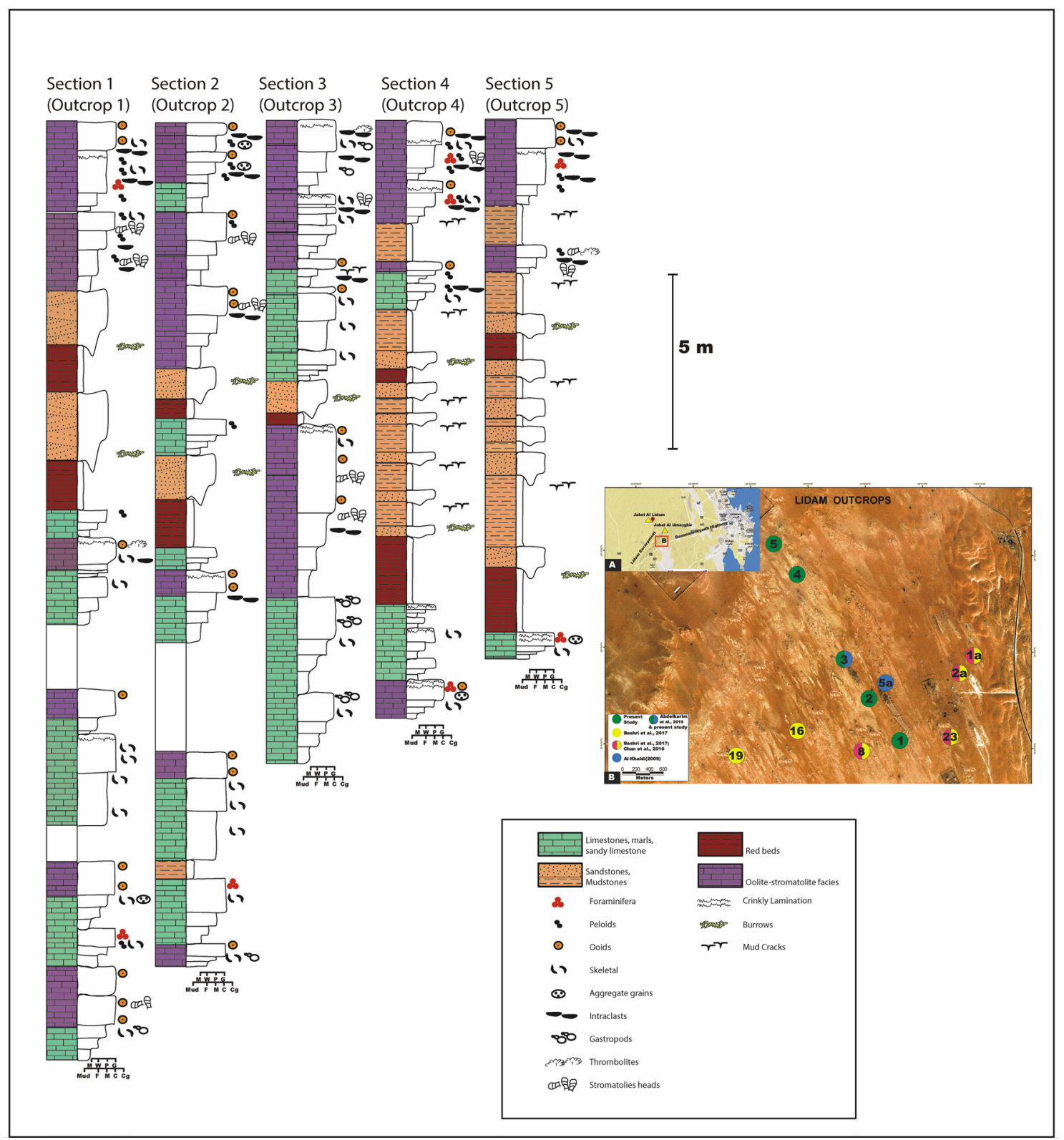

Fig. 2 Lateral distribution of facies through the studied outcrop, northwestern outcrops, 4, 5 rich in siliciclastic facies, and the southeastern outcrops more dominated by carbonate facies, inset map of showing the location of the section from this figure

contain abundant stromatolite clasts, derived from columns. These intraclasts fill the gap between the stromatolite columns (Fig. 3). The microscopic texture of the columns presents dense mudstone-wackestone laminations. Grain types are intraclasts, ooids, pellets, and fenestra (Fig. 3). The ooids are oriented with fenestra and seem to fill the gaps between individual columns. Quartz and skeletal particles are a subordinate component of this facies. The facies has a total porosity of $3-5 \%$, with mouldic being the dominant type, with a permeability of $0.01 \mathrm{md}$.

Interpretation Stromatolitic boundstone facies is corresponding to FZ7 and SMF 16 facies (Wilson 1975; Flügel
2010). Isolated columns, the fenestral texture of the stromatolites, indicate that they have a similar depositional environment like the oolitic grainstones. The depositional environment that started with the growth of stromatolites and become transitional to oolitic grainstones was probably subtidal to intertidal.

Gastropodal grainstone Description It was named formerly mollusk packstone (Alkhaldi 2009) and massive peloidal skeletal packstone (Bashri et al. 2017).This is the basal facies encountered in the study $\mathrm{N}-\mathrm{S}$ section of the Al-Lidam escarpment. The facies described from outcrops 


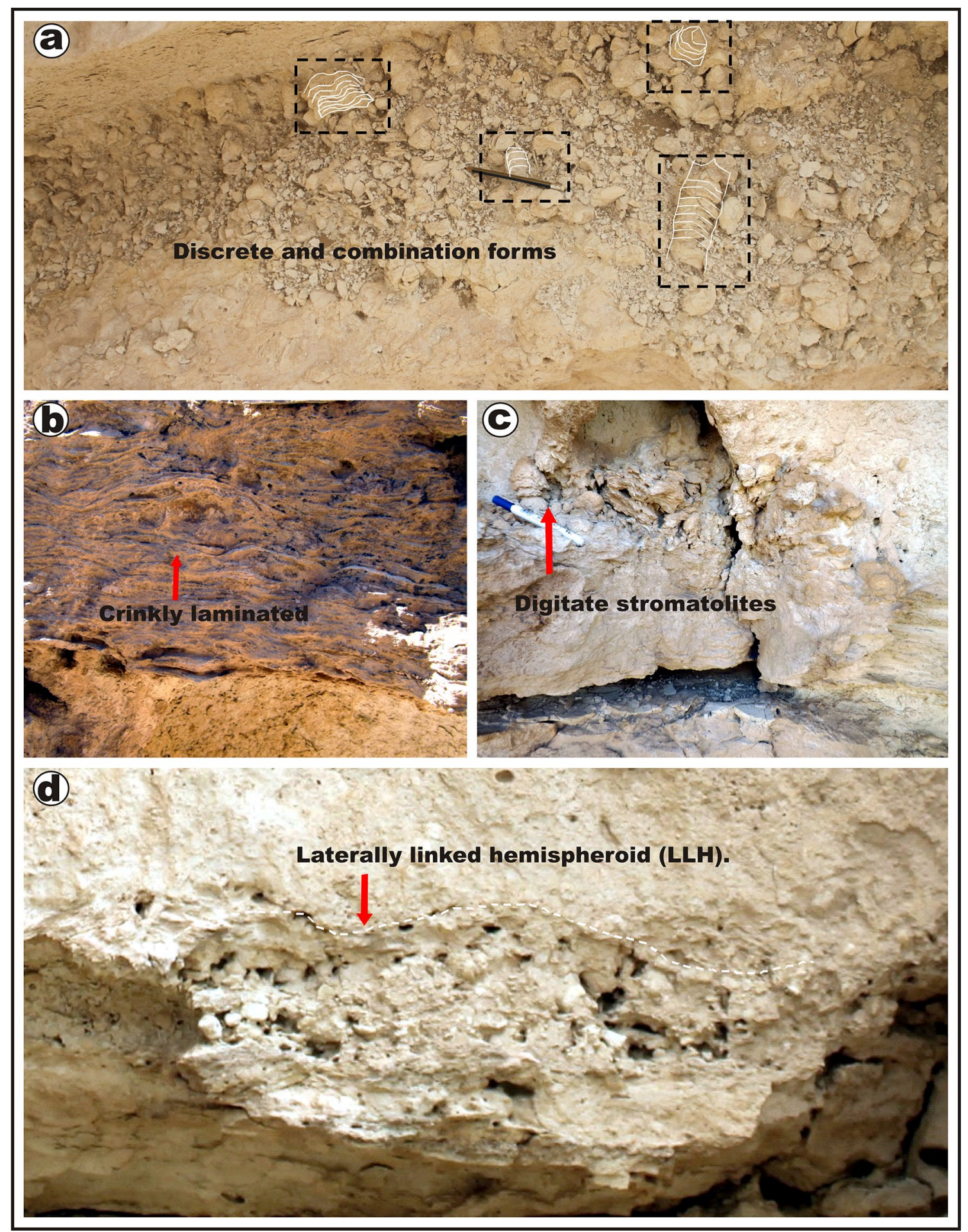

Fig. 3 Stromatolite morphologies in the Dam Fm. a Discrete and combination forms of stromatolite heads. b Crinkly lamination, microbialite. c Digitate stromatolite closer look. d Laterally linked hemispheroid

1,2 , and 4 has increased skeletal components in outcrop 4 (Fig. 2). The tan to creamy, trough cross-bedded facies, silt to pebble size grain size, is approximately $190-200 \mathrm{~cm}$ and is made up of gastropods, other skeletal debris, and ooids (Fig. 4a, b). Skeletal moulds are dominant pore types along with vuggy porosity. Micritization along with leaching of fragments is a leading diagenetic process in 
Fig. 4 a Cross-bedding in gastropod facies. b Ripple crosslamination in gastropods grainstone facies. c Field photograph represented by foram-mollusc pack-grainstone with a karstified surface, overlain by mudrock, that is in turn capped by stromatolitic boundstone. $\mathbf{d}$ Mega fracture on the western side of the outcrop 3, starting with the base of sandstone not exposed, overlain by foram-mollusc packgrainstone, mudrock, stromatolitic boundstone, microbial ooid grainstone and capped by thrombolitic boundstone facies. e In the field photographs from the western side of outcrop 3, basal most unit is presented by red beds (paleosols) overlain by channelized sandstone, foraminifera mollusc packgrainstone and stromatolite boundstone facies
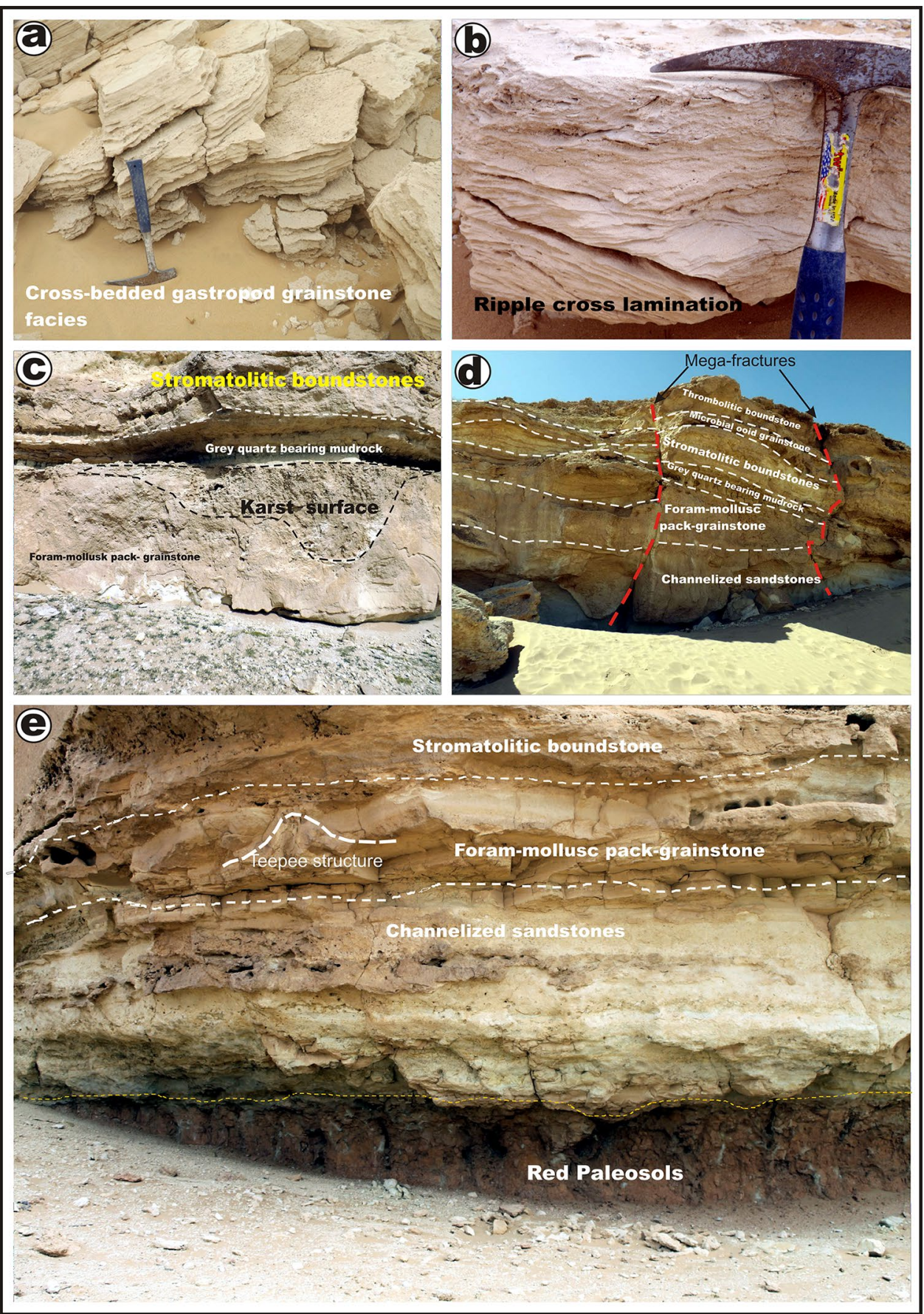

the facies. The total porosity of this facies ranges from 10 to $15 \%$ with a permeability of about $0.1 \mathrm{md}$.

Interpretation This facies corresponds to FZ 6 and SMF 11 facies (Wilson 1975; Flügel 2010). As indicated by faunal diversity of the facies, it was deposited in the regions above the wave base with normal marine salinity in a skeletal bank setting (Hallock and Glenn 1986). The coating on grains occurs because of micritization by microborers that took place, preferably in the early diagenesis.
Present-day examples of skeletal banks are from South Florida (Enos and Perkins 1977).

Oolitic grainstone Description It was previously described as carbonate oolitic grainstone (Alkhaldi 2009) and planar cross-bedded skeletal peloidal grainstone (Bashri et al. 2017). This creamy white to tan, and crinkly laminated medium-grained and low-angle cross-bedded facies with 20-100-cm-thick beds, is majorly made up of ooids (Fig. 6e). The facies makes the topmost part of the flat- 
topped steps as seen from a distance in Dam Fm. The facies occurred in outcrops 1 and 2, above the stromatolite boundstone and gastropod grainstone facies. In outcrop 3, it covers the foraminiferal mollusc pack-grainstone. The sheet-like geometry is the characteristic of Dam Fm. cycles. In the updip section, outcrop 4, quartz content increases to $30 \%$ in the facies while skeletal fragments in outcrop 3, increased by $20 \%$. In petrography, the ooids show inverted porosity, as grain become pores and pores are cemented by isopachous to blocky cements. In outcrop 1 , abundant intraclasts of underlying stromatolite heads are also observed. The ooids are well rounded and sorted (Fig. 7e). The porosity in facies ranges from 20 to $25 \%$.

Interpretation This facies is the same as FZ 6 and SMF 15 (Wilson 1975; Flügel 2010). Oolitic deposits in Dam Fm. are very significant and are of typical character. The facies of skeletal bank (gastropod grainstone) and intertidal (stromatolite boundstone) grade are upward into hypersaline shoal (oolitic grainstones) conditions. With the low diversity of faunal and lithological character, the oolitic grainstone facies was deposited in a shallow subtidal-intertidal setting (Longacre and Ginger 1988; Scholle et al. 1983).

Microbialite intraclastic packstone Description It was termed earlier as carbonate laminite/stromatolites (Alkhaldi 2009), trough cross-bedded aggregate intraclast oolitic grainstones (Bashri et al. 2017), and intraclastic oolitic grainstone (Abdelkarim et al. 2019). This microbialite intraclastic packstone is light tan to creamy $1.5-2.0 \mathrm{~m}$ thick (Fig. 4d; 6f). The packstone is composed of peloids and intraclasts of variable sizes, ranging from sand to gravel (Fig. 5a). The matrix is fine lime mudstone. In the lower part, facies are structureless and become crinkly laminated in the upper part. This facies overlies stromatolitic boundstone and underlies microbial ooid grainstone. Locally, this facies is cemented with bladed calcite cement. The dominant type of porosity is moulds and vuggy. The porosity in facies ranges from 10 to $12 \%$ (Fig. 5a).

Interpretation The contrast of this facies suggests a moderate energy-driven shallow subtidal setting (Palma et al. 2005). This facies was a by-product of reworking and erosion of pre-existing facies. Subrounded to subangular aggregate grains and intraclasts are interpreted to be deposited in a shallow lagoon (Platt 1989; Ali 2020; Ali et al. 2021b). The occurrence of this facies along with stromatolitic boundstone, and microbial ooid grainstone indicate shallow nearshore settings, as in the Arabian Gulf and Shark Bay (Wagner and Togt 1973).

\section{Qaurtz Ooilitic-peloidal-molluscal grainstone Description} It was described as lime/clay clast quartz wacke, quartzose marl and peloid mudstone (Alkhaldi 2009), skeletal ooidal grainstone, ooidal grainstone and skeletal peloidal (Chan et al. 2017), channelized planar cross-bedded skeletal oolitic grainstone, dipping planar-bedded skeletal oolitic grainstone and herringbone cross-bedded skeletal oolitic grainstone (Bashri et al. 2017), quartz fossiliferous wackestone-packstone and skeletal ooilitic-peloidal grainstones (Abdelkarim et al. 2019).This facies underlies the mud facies in outcrop 5 (Fig. 2). The facies is highly cemented and it overlies microbialite intraclastic packstone with a sharp contact. Fine to light pink to tan coloured, medium grained moderately to poorly sorted grains fluctuate in thickness from 0.5 to $1.2 \mathrm{~m}$. The majority of the grain types are ooids, molluscs, intraclasts, and other skeletal debris. Some of the skeletal grains are dissolved and their outer moulds are preserved by micritic envelopes. Porosity in this facies varies from 12 to $15 \%$ (Fig. 5b).

Interpretation This facies corresponds to SMF 16 and FZ8 (Wilson 1975; Flügel 2010). Ooid-peloid grainstone beds, with the presence of mollusc fragments, indicate highenergy depositional environment (James et al. 2004). Lateral repetition and absence of this facies indicate migrating oolitic shoals during its deposition (Dantas and Holz 2020).

Microbialite ooid grainstone Description This facies is tan and $20 \mathrm{~cm}-1 \mathrm{~m}$ thick, and commonly caps stromatolite boundstone (Fig. 4d). Beds are characterized by an upward fining trend, and some have bidirectional cross-bedding, fine- to coarse-grain sand-size ooids, sand to less common gravel-sized mollusc, with variable amounts of quartz (from 0 to $10 \%$ ), and rare gravel-sized ooid-grainstone intraclasts.

Interpretation This facies belongs to the SMF14 of Flügel (2010). The microbial ooids were formed in tidal deltas, beaches high-energy shoals in a tropical location, probably during a time of increased worldwide warmth (Woods 2013). A lack of widespread development of microbial conditions on the Dam ramp indicates that the grazing stresses were tough to retain microbial growth. The thin to medium bedding of the oolitic units representing the oolitic facies suggests that they did not form oolitic barriers, but rather thin oolitic sheets or caps on sublittoral oolitic-peloidal-molluscal grainstone facies (Alsharhan 1993). This microbial ooid grainstone formed on beaches, tidal bars, and oolitic sandflats is analogous to those forming today in Arabian Gulf and Shark Bay (Alsharhan and Kendall 2003).

Thrombolitic boundstone Description Thromobolitic boundstone has carbonate laminite (Fig. 4d) and is relatively rare. The beds of the facies are $0.2-2 \mathrm{~m}$ thick. It overlies the microbial ooilitic grainstone facies, and it underlies ooiliticpeloidal-molluscal facies. The facies has local stromatolitic to structureless features. Some of the pores are filled by evaporitic minerals probably gypsum. Laminae consist of alternating peloid grains (fine to medium sand-size grains), a variable amount of quartz grains, along carbonate mud. 


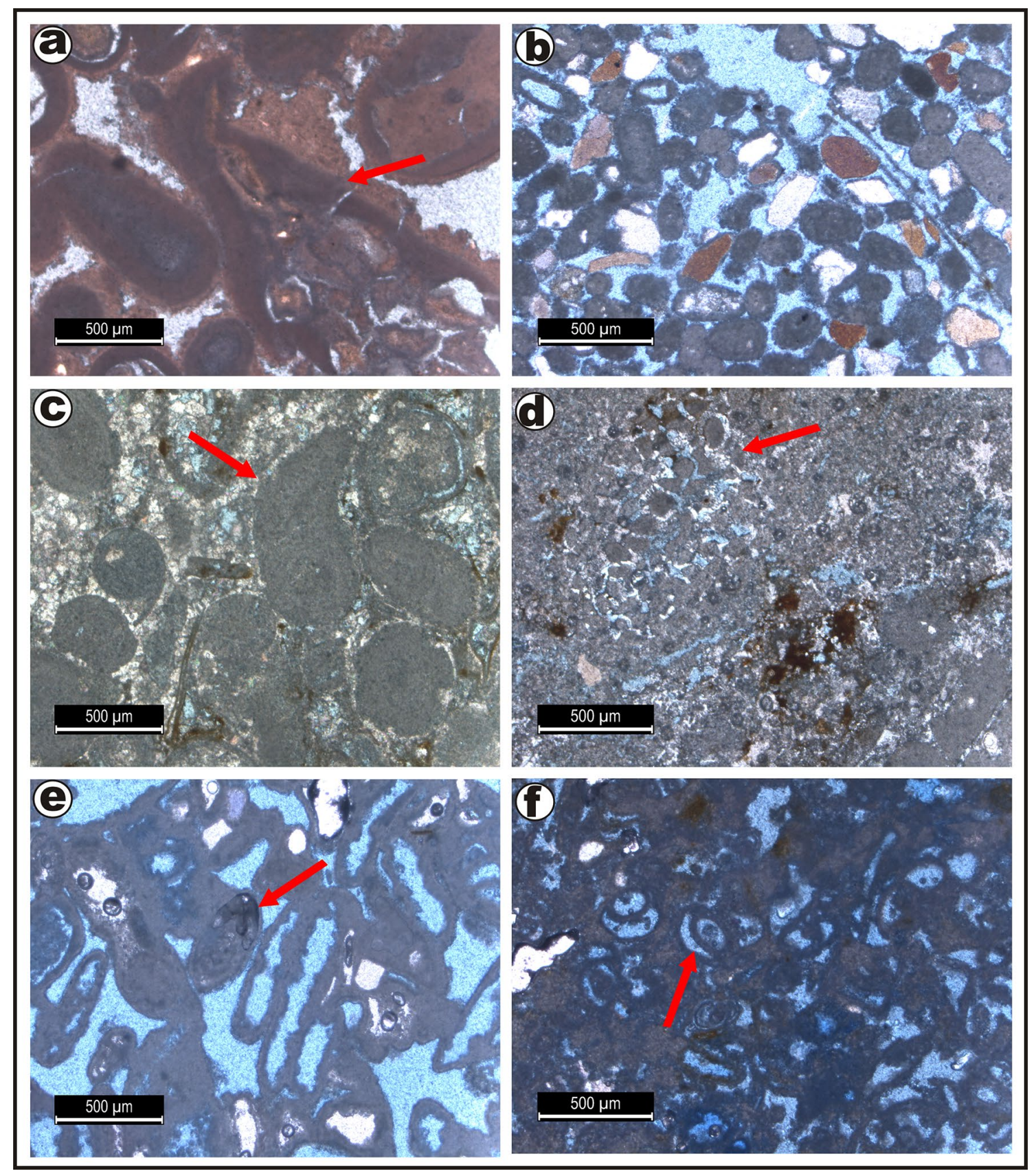

Fig. 5 Microphotographs of Dam Fm. facies. a Microbilate intraclastic packstone facies, with bladed calcitic cement, that indicates vadose diagenesis. b Ooid-peloid grainstone with quartz grains facies have grain dissolution features. $\mathbf{c}$ Gastropods grainstone facies with strong cemented fabric. d Microbial ooid-grainstone facies, with ooid grains coated with algal laminae. e Foram-mollusc pack-grainstone facies, larger benthic foraminifera, with dissolution and creation of mouldic and vuggy pores. f Foram-mollusc pack-grainstone facies, miliolids, with micritic grains show the presence of lagoonal conditions
Internally, these boundstones also have quartz grains, pellets, and peloids, giving them the appearance of fenestrae and microbial binding.

Interpretation The outcrop of Dam Fm. in the Al-Lidam gives the appearance of a carbonate mound. The thrombolite gives it biostromal or coalescent mound shape with a height of $1 \mathrm{~m}$ or more. These mounds are closely associated with stromatolitic boundstones facies (Zhang et al. 2015). However, according to Alkhaldi (2009), this facies was not encountered in the core samples of shallow subsurface from the Al-Lidam area. The thrombolite mounds, although they grow similar or some time on the digitate stromatolitic facies (Pratt 1982; Zhang et al. 2015), appear to lack distinctive internal fabrics that are characteristic of thrombolitic facies, 
Fig. 6 a Channelized sandstone facies, overlain by a sharp contact of mudcracks bearing mudrock, this is followed by stromatolitic boundstone facies. b Foram-mollusc pack-grainstone facies overlain sharply by mudrocks. c Mudcracks filled with sandy material, closer view of grey mudrock. d Teepee structure in forammollusc pack-grainstone facies. e The northern face of outcrop 3 indicates the presence of microbial ooid-grainstone facies overlying mud cracked grey mudrock, next overlying the succession is sheeted microbial ooid grainstone, in turn, underlying stromatolitic boundstone, microbial intraclastic packstone, microbial ooid grainstone, and thrombolitic boundstone (giving it a mound shape)
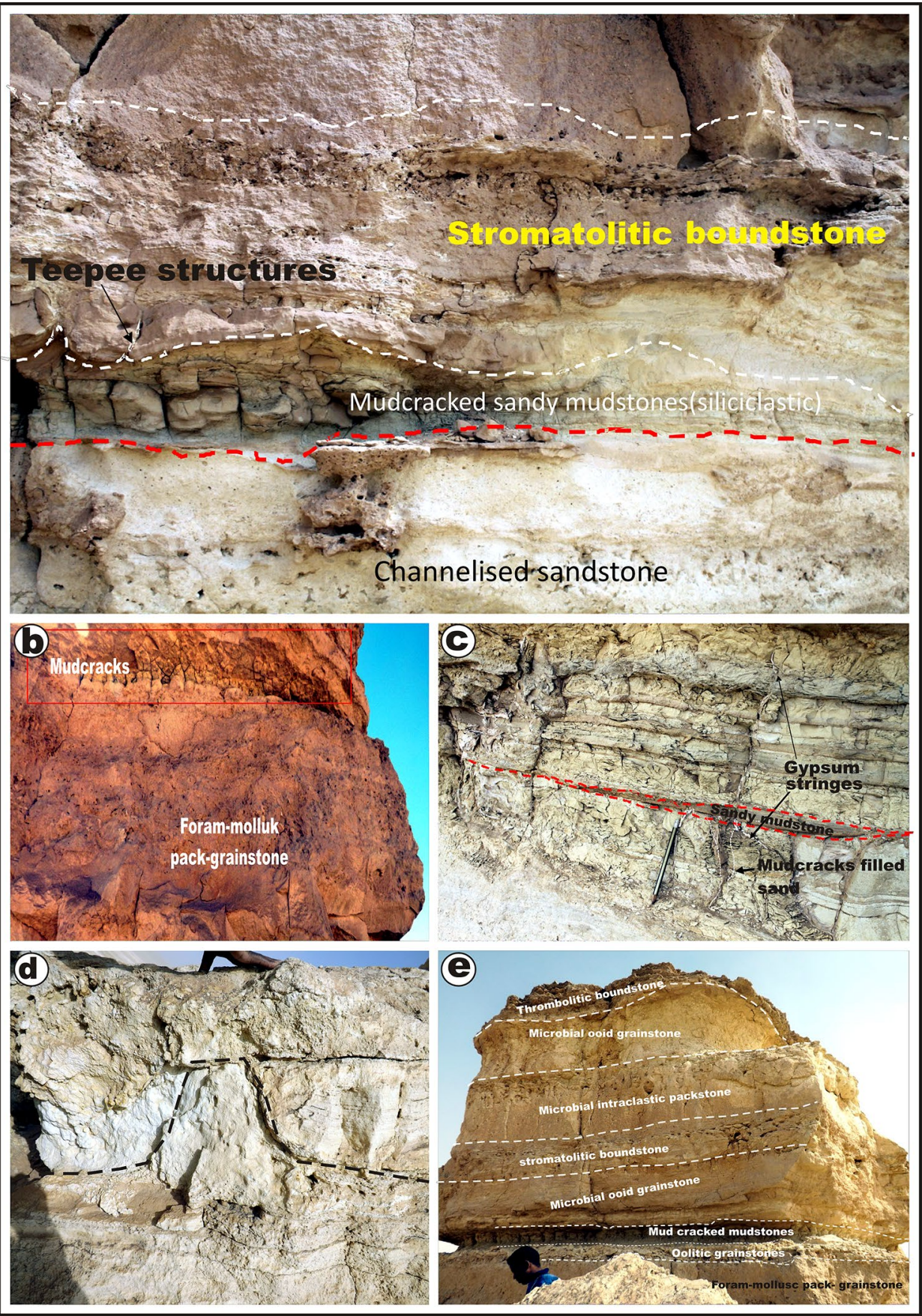

i.e. thrombolitic fenestrae and clots (Armella 1994). Hence, our interpretation is entirely based on its mound-shaped geometry.

\section{Foraminiferal Mollusca (gastropods) pack-grain-} stone Description It earlier was designated as brecciated carbonate sheets and foraminiferal mollusk pack-rudstone (Alkhaldi 2009). The facies varies from tan to creamy, with bed thickness varying from 100 to $170 \mathrm{~cm}$ (Fig. 4c, d, e). Most grain types are foraminifera, gastropods, and peloids with a minor amount of quartz. The particles are coarse- grained with angular to subangular in shape. Skeletal fragments have coarse-grained to scattered pebble grain size. This facies has teepee and crinkly laminated structures. It overlies channel sandstone facies and underlies ooid-grainstone facies in outcrops $1,2,3$, and 5. In outcrops 2 and 4 , the foraminifera decrease in abundance and are replaced by bored bioclasts. In outcrop 1 , the facies is dominated by larger foraminifera. SEM analysis reveals (Fig. $7 \mathrm{~g}$ ) high-resolution images of foraminifera with some corrosion in the shell and surrounded by micrite. EDS analysis present that the peaks of $\mathrm{Ca}$ and $\mathrm{Mg}$ show (Fig. 7h) that facies contains 


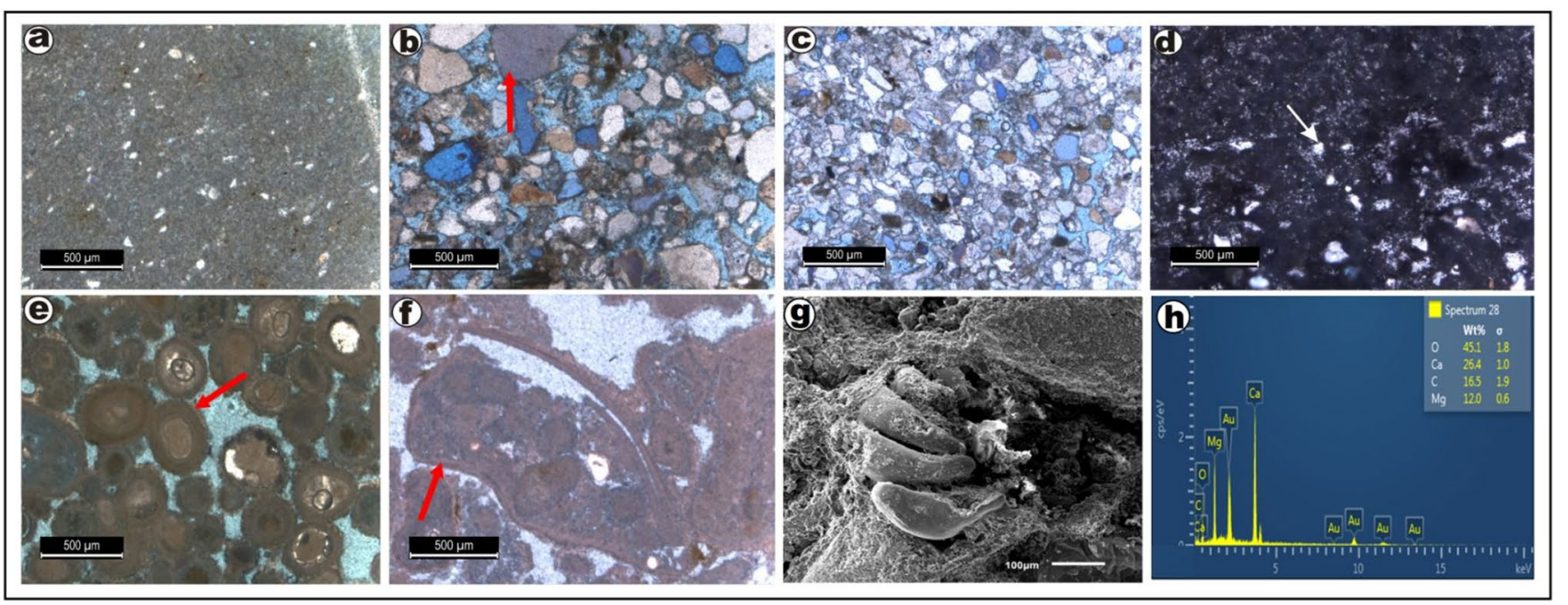

Fig. 7 Microphotographs of Dam Facies. a Photomicrograph from grey-green mudrock, indicating fine quartz. b Channel sandstone facies. Interparticle is the dominant porosity type. c Shaley calcareous sandstone. d Stromatolitic boundstone, quartz grains entrapped. e Ooid grainstone, with vadose diagenesis, having meniscus and acicular to bladed calcitic cement, it is made up of ooids; medium to coarse size of the ooids, with some skeletal fragments with micritized envelopes and intraclasts, mouldic is the dominant porosity. f Microbialite intraclastic packstone, large clasts are composed of ooids and shows deposition with microbial fabric and eroded into the present facies. g SEM images of foraminfera in carbonate mud. $\mathbf{h}$ EDS analysis of foraminfera, shows abundance of $\mathrm{Ca}$ and $\mathrm{Mg}$ a minor amount of dolomite. The facies is characterized by mouldic and intraskeletal pore types. The porosity in the facies ranges from 10 to $20 \%$ (Fig. 5e, f), and permeability is about $0.01 \mathrm{md}$. Calcite (86\%) is the dominant mineral, while quartz and accessory minerals account for $14 \%$ of the bulk mineralogy.

Interpretation Foraminifera occur as the concentration of tests in tidal bars and channel of lagoons (SMF 18; FZ 8 and FZ7 Wilson 1975 and Flügel 2010, correspondingly). The diversity of foraminifera, sedimentary structures, and grain size indicates high energy and deposition in distal ramp margin to lagoon over the fair-weather wave base (Scholle et al. 1983; Brachert 1992; Saw et al. 2017, 2019; El-Yamani et al. 2018; Bi et al. 2019; Awais et al. 2019; Mohammadi 2020; Kamran et al. 2020). The bad sustentation of the foraminifera existing as moulds in thin sections restricted their naming to genus level. This facies presents the most diverse assemblage in terms of foraminifera. The forms include larger foraminifera as well as miliolids (Triloculina, Quinqueloculina), followed by Cornuspira, Cibicides, Coscinospira, Elphidium, Peneroplis, and Operculina (Chan et al. 2017).

\section{Mudrock Facies}

Red-Paleosol Description The facies was named erstwhile as paleosols and red mudrock (Alkhaldi 2009). The thickness of this facies is red to dark brown, structureless, facies, varies from 75 to $200 \mathrm{~cm}$. It is dominantly composed of mudrock with thin sand thin lenses (Fig. 4e). The dominant sedimentary structures are mudcracks and rhizocretions. Mudcracks are evident on bedding plane surfaces. Plant roots or rhizoliths can contribute to a variety of textures in carbonates-siliciclastic successions. In Dam Fm., we have a ramifying network of branches of rhizoliths along the bedding planes.

Interpretation This mudrock is a part of paleosols. Their structure is somewhat like the recent soil horizon. This facies underlies the channelized sandstone in outcrops 2 and 3, is stratigraphically significant, and represents a period of non-deposition. This non-deposition marks a sequence boundary between two directly overlying sequences. Rhizoliths are abundantly reported from Quaternary terrestrial carbonates from Western Mediterranean. It is an indicator of paleosols and subaerial vadose diagenesis of post-Silurian rocks (Klappa 1980). Alkhaldi (2009) used this red mudrock to demarcate sequence boundaries (unconformities) within Dam Fm. Mud cracks indicate desiccation due to subaerial exposure (Scholle et al. 1983) at the time of Dam Fm. A recent example exists in Kalahari Basin, South Africa, where a fluctuation between dry and lacustrine conditions exists (Botha and Hughes 1992).

Grey-Green quartz-bearing mudrock Description It was formerly known as grey-green mudrock (Alkhaldi 2009), interbedded mudstone and evaporites (Chan et al. 2017; Bashri et al. 2017), and desiccated mudstones and quartz mudstones (Abdelkarim et al. 2019).This green to dark brown facies overlies the channelized cross-bedded sand-

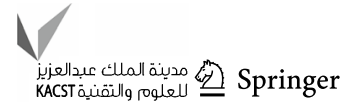


stone facies in outcrop 3 and shaley calcareous sandstone in outcrops 4 and 5. Its bed thickness ranges from 50 to $300 \mathrm{~cm}$. The facies occurs as alternating light mudrock and minor siltstone interbeds (Fig. 4c). The grain size of the facies ranges from clay to silt size. The top bed surfaces are signified by mud cracks. The mudcrack length depends on the bed thicknesses and varies from 15 to $20 \mathrm{~cm}$. The geometry of the crack is planar to irregular depending on the compaction of the sediments after deposition with filling by fine sand materials. The porosity in this facies is tight, with less than $1 \%$ (Fig. 7 a).

Interpretation Mudcracks layers would indicate intertidal deposition and subsequent exposure. The fine siltstone layers indicate a mixed mud-silt tidal flat blanket after the exposure of the ramp. This facies was deposited under quiet water with an arid climate, high oxygen levels, hypersaline, and shallow lagoonal conditions. Deposition in shallow water is suggested by sedimentary features in associated sediments, indicating a period of exposure and reworking (Reineck and Singh 1980).

\section{Sandstone Facies}

Channelized cross-bedded sandstone Description The facies was named quartz sand sheets (Alkhaldi 2009), channelized medium sandstone facies (Bashri et al. 2017), and estuarine sandstones (Abdelkarim et al. 2019). The sediments are very fine to medium grained, tan to light green, moderately to poorly sorted, $50-200 \mathrm{~cm}$ thick, and bioturbated (Fig. 4d, e, 6a). The sand beds overlying the red mudrock are also marked by rhizoconcretions or root traces (Fig. 8a, Fig. 8b and Fig. 8g). The diameter of these trace markers is from 25 to $30 \mathrm{~cm}$. Mineralogically, it is a quartz arenite, with accessory minerals less than $5 \%$ cemented by clays (Fig. 7b). The mudrock occurs as small lenses and interbeds within the thick sand body in outcrops 4 and 5 (Fig. 8). The prominent sedimentary structures in the facies are cross-bedding, channel, and channel lags. Syn-depositional deformation structures or seismites are visible in the facies in outcrops 1, 2, and 3 (Fig. 9).

Interpretation The mineralogy, texture, and grain size of the sandstone beds suggest rapid deposition. Based on rock type and sedimentary structures, the sandstone was deposited in intertidal and coastal shallow marine sand sheets (Alkahldi 2009; Bressan and Palma 2009; He et al. 2019). The presence of clay mineral palygorskite indicates recycled sediments in the basin that provided time for growth. The rhizoconcretions reflect exposure and subaerial substrate at the time of deposition. The surfaces along with rhizoconcretions occur were formed following a sea-level fall. The present-day estuarine channel in Willapa Bay, Washington, can be considered as an analogue of this facies (Frey and Howard 1986).
Shaley calcareous sandstone Description It was termed as brecciated micritic quartz sand gypsiferous calcareous sand (Alkhaldi 2009), sandstone and mudstone (Chan et al. 2017), interbedded cross-bedded sandstone and mudstone facies (Bashri et al. 2017), and calcareous sandstone (Abdelkarim et al. 2019). It is light grey, yellow, reddish, very fine to medium grained, and slightly bioturbated, moderately to poorly sorted, 20-120-cm-thick sandstone (Fig. 8d). Mineralogically, a quartz wacke is composed of fine- to mediumgrained quartz, subangular-angular, with clay and orthoclase matrix. This sheet cross-bedded sandstone occurs as a major facies in outcrops 4 and 5 . The other sedimentary structures in this facies include tidal bundles, climbing ripples, mud drapes, and wavy bedding. The sandstone is cemented by carbonate cement (Fig. 7c). From south to north, the balance of sand and mud becomes identical as we move along transect. The thickness of beds changes with a sand content that declines upwards. In outcrop 5, bioturbations are rare. There are no trace fossils present in the upper sand bed. The prominent sedimentary structure in this facies is cross-bedding. The facies has a geometry of a sheet and emerges as a valley blanket.

Interpretation This sandstone facies is devoid of any significant morphological character. The beds destruction by bioturbations indicates deposition in a lower shoreface (Kumar and Sanders 1976; Anan 2014). The existence of mudrock interbedding thick sandstone lenses elucidates sporadic events of low energy. The scarcity of fossils specifies deposition under high-energy settings and hypersaline conditions. The thick beds of sand represent rapid deposition.

\section{Discussion}

The Arabian Plate head-on collision with the Eurasian Plate during Late Oligocene to Early Miocene led to the growth of Zagros orogenic belt and subsequent closure of the NeoTethys Sea (Ziegler 2001; Ghasemi and Talbot 2006). Alpine orogeny took place mainly during the Burdigalian stage of Miocene (Guerrera et al. 1993). Powerful compression occurred as the Arabian plate was driven towards Eurasia and separated from the African plate (Reilinger et al. 2006).

Throughout this period, terrigenous deposits in a continental foreland basin replaced the primarily carbonate foredeep basins (Sharland et al. 2004; Boulton and Robertson 2007). The sediments were deposited in the foredeep and foreland of Zagros (Pirouz et al. 2011). This was the time of opening of the Gulf of Aden and rifting of Arabian and African plate started that gave birth to the narrow Red Sea (Hempton 1987). The complicated strike-slip structuration along the Dead Sea transform fault resulted in the uplift of the Syrian Arc (Gomez et al. 2007). 
Fig. 8 a Network of rhizoconcretions, on the lower bed of channelized sandstone bed. $\mathbf{b}$ Root traces in grey mudrock. c Mudcracks bearing mudrock succession with channelized sandstone interbedding, overlain by calcareous sandstone, topped by microbial ooid-grainstone facies. d Channelized sandstone facies, overlain by grey mudrock, calcareous sheeted sandstone facies, and capped by microbial ooid-grainstone facies. e Weathered section of outcrop 1, with foram-mollusc pack-grainstone, overlain by paleosol, and channelized sandstone facies. f Channel lag in channelized sandstone facies
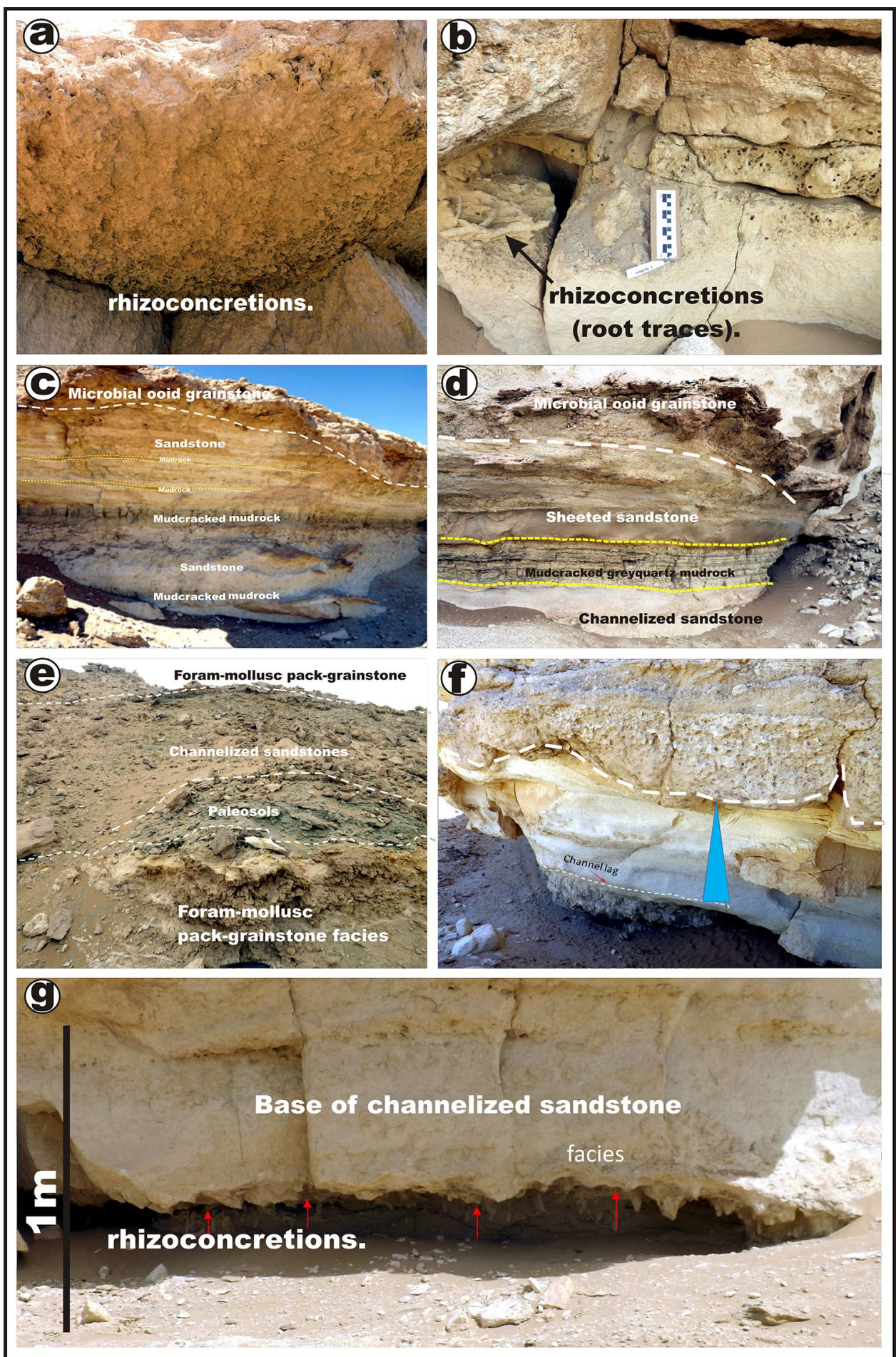

This was the time of deposition of Hadrukh, Dam, Hofuf (Saudi Arabia), and Agha Jari, Gachsaran (Iran), Fars and their regional counterparts with huge salt accumulation [MFS Ng10 to post-Ng40] (Ziegler 2001). A dominant continental clastics of Hadrukh Fm. and transitional Dam Fm. was formed across the Arabian Arch (Ziegler 2001). As a consequence of the Arabian-African plate, the Arabian Platform gradually inclined to the 
Fig. 9 a Channelized sandstone, underlying syn-sedimentary structures, distorted beds that could be the result of seismisite, overlain by microbial ooid grainstone. b Seismisite at outcrop scale, 1. Basal beds (non-deformed), 2. Uprising of sandy beds, 3. Pieces of lower bed, flow like incompetent sediments, 4. Preserval of depositional fabrics of distorted bed, 5. Outward movement of discharged sediments, 6 . Nondeformed beds on the upper sedimentary layers

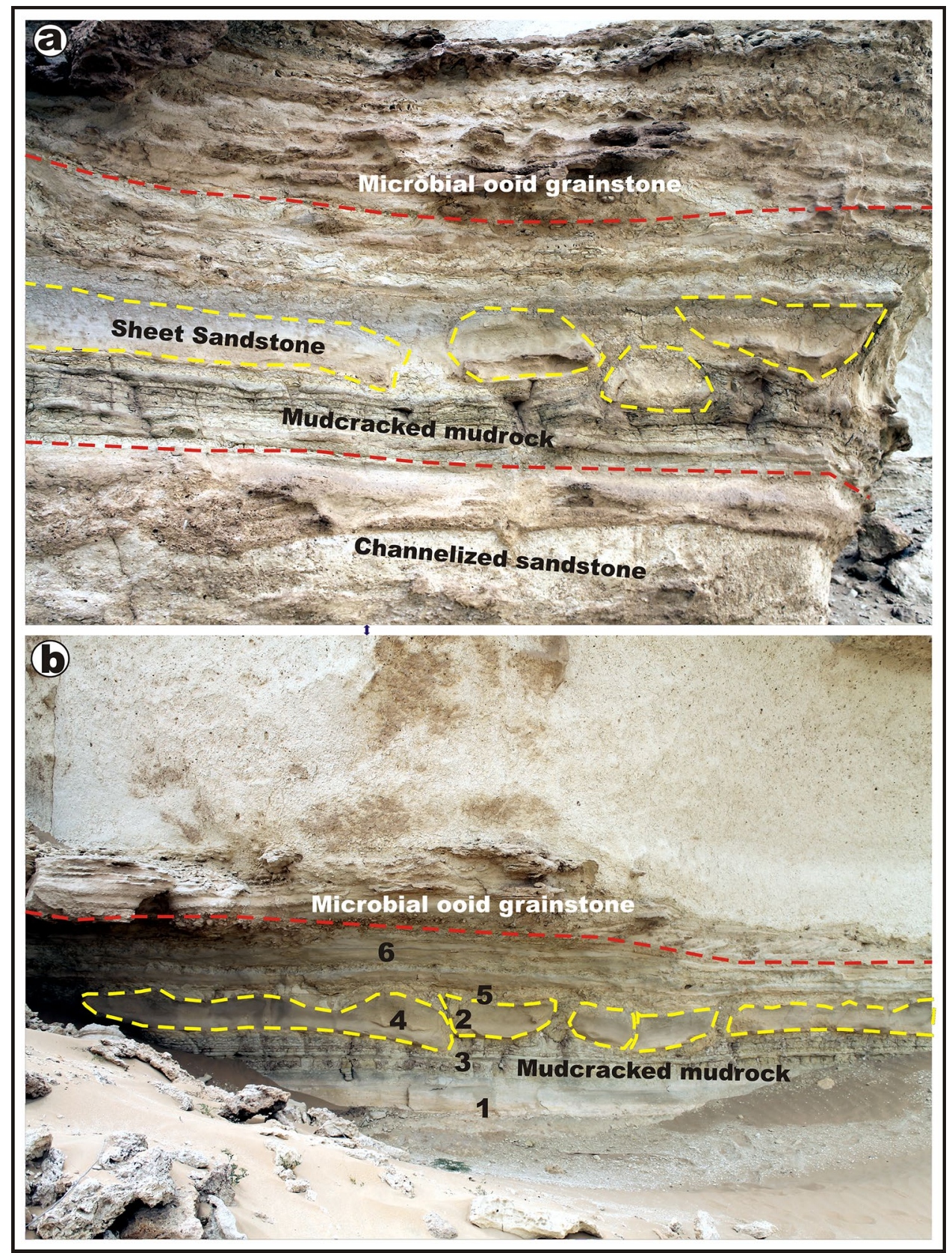

northeast. As a result of the rifting of the Arabian and African Plates, the Arabian Plate gradually tilted to the northeast (Ziegler 2001). Subsidence in the area of interest is defined to have been caused mostly by the structural loading of the Zagros thrust sheets (Sharland et al. 2004) or activation of basement normal faults that provided necessary accommodation space.

\section{Facies and depositional setting}

The lower contact is placed at the change from the Hadrukh Fm. sandstone into marl (fossiliferous) and limestone of Dam Fm. (Mukhopadhyay et al. 1996). The Dam comprises of varied marls and shales, with some beds of chalk, limestone, and coquina (Alsharhan and Narin 1995). The Dam shelf was submerged and became deeper (middle to outer ramp) along with the presence of skeletal bioclasts, foraminifera, and gastropods facies. The gastropod grainstone facies is formed in regions above the wave base with normal marine salinity as indicated by some faunal diversity in the facies. The coating on grains occurs as a result of micritization by microborers that take place preferably in early diagenesis.

The depositional environment became shallower (middle ramp) and allowed the formation of a shoal. This resulted in the deposition of oolitic-peloid grainstone facies. 
Ooid-peloid grainstone beds, with the presence of mollusc fragments, indicate high energy. This is a sort of barrier facies between shallow and deep depositional environments. Shoal forms in the middle of lagoonal and deep ramp setting, and also serve as a barrier from waves and currents (Flügel 2010).

\section{Subtidal-Intertidal setting}

According to previous authors (e.g. Tleel 1973), the Dammam Dome is in the Eastern Province and was covered by early Miocene transgression. During the onset of the transgression, the first product was stromatolites that grew around the dome. As the Dammam Dome is about $70 \mathrm{~km}$ from the study area towards the present shoreline, stromatolites may have also grown during the same transgression in the Al-Lidam area (Irtem 1986). Hence, there might have been a low-lying structural horst in the area, where stromatolites started to grow like in the Dammam Dome (Irtem 1986). As evidenced by our results, the depositional environment became shallower and restricted and led to the formation of stromatolites (Fig. 3). The individual pillar to column shape, pore or fenestral fabric, and association with oolitic grainstone signify a depositional setting similar to oolitic grainstones. The depositional environment became more agitated hypersaline shoal throughout the settlings of later facies.

The oolitic grainstone facies occurs as sheets (Irtem 1986) and is a typical character of the Dam Fm. (Fig. 7f). Skeletal bank (gastropodal grainstone) and intertidal (stromatolite boundstone) grade upward into hypersaline shoal (oolitic grainstones). The low diversity of faunal and lithological character of the oolitic grainstone facies shows that it was deposited in a shallow intertidal to the subtidal setting (Scholle et al. 1983). The presence of low-angle cross-bedding, stromatolitic debris, and close association with the stromatolitic boundstone facies indicates that the conditions were not changed, except the increase in tidal/wave action and hypersaline setting. The oolitic sheets could have been a large blanket with partly quartz influx, foraminifera, and skeletal allochems in the Al-Lidam region.

The minor fluctuations in the depositional setting were consequent to the change of subsidence conditions in the Zagros basin and were marked by microbial ooid-grainstone deposition (Fig. 6f). The thin to medium bedding of the oolitic units represents oolitic facies and suggests that they did not form oolitic barriers. However, they formed thin oolitic sheets or caps on sublittoral ooid-peloid-mollusc grainstone facies (Loreau and Purser 1973). A lack of widespread development of microbial for entrapping ooids indicates that the grazing stresses were tough to limit the microbial formation. The depositional conditions became moderate energy and incorporated intraclasts in the facies. Such microbialite intraclastic packstone facies were possibly caused by the erosion of the storm surge and the rework of various shallow marine sediments (Flügel 2010).

The depositional setting of Dam Fm. became subtidal leading to the development of thrombolite-like mounds (Fig. 4d, 6f). It lacks the typical microbial clots and fenestrae internal fabric. The outcrops of Dam Fm. in the Al-Lidam area give the appearance of a carbonate mound (Alkhaldi 2009).

\section{Estuarine to continental setting}

Clastic input in the form of tidal channels is considered here the controlling factor on the distribution of stromatolites in the Dam sequence (Irtem 1986). The formation of intraclasts and overlying oolitic grainstone facies with low-angle crossbeds, in places, indicates robust wave action. The repeated action of waves and currents led to agitation and winnowing that developed the algal over the carbonate sediments (Fig. 7f). The richness of coatings and peloids with micritization suggests low rates of sedimentation, however, lacking any subaerial exposure. The individual algal mats with fenestral fabrics and columnar shape growing on the lower intertidal flats of the Hamelin Pool, Western Australia (Hoffman 1976), and Devonian stromatolites of Canning Basin are quite similar to the one in study area. Recent examples of ooid shoals are found in the Arabian Gulf, which is not far from area of interest. In this hypersaline sea, ooids are formed in lower intertidal to shallow subtidal settings. Exemplified in Bahamas Bank's, Joulters ooid sand shoal, their deposition is also affected by strong winds.

The low rates of subsidence $(\sim 1 \mathrm{~cm} / \mathrm{k} . \mathrm{y})$ in the study area indicate that the facies was exposed to $20-40 \mathrm{~m}$ of sea-level fluctuations, during falling sea level (Abreu and Anderson 1998). Localized thin paleosols or red-bed (Fig. 4e) cap the oolitic grainstone facies representing the emergence of the Dam Fm. Their structure is somewhat like recent soil horizon mudrocks/paleosols, which were previously used by, e.g. Alkhaldi 2009 to establish unconformities in Dam Fm. This facies is of great stratigraphic significance as it illustrates the time of sequence boundary/non-deposition in Dam Fm. Rhizolith (also reported by Chan et al. 2017) is an indicator of paleosols and subaerial vadose diagenesis in post-Silurian rocks (Klappa 1980).

Our results show that because of sea-level fall, the clastic sediments covered the carbonate facies (Fig. 2). The relative sea level after the formation of red beds but was not so pronounced in the onset of carbonate deposition and as an alternative allowed the deposition of channelized crossbedded sandstone. The mineralogy, texture, and grain size of the sandstone beds suggest rapid deposition. Based on rock

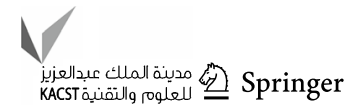


type and sedimentary structures, the sandstone was deposited in intertidal and coastal shallow marine sand sheets (Alkahldi 2009; Bressan and Palma 2009). However, Chan et al. (2017) suggested deposition in a supratidal to a shallow intertidal, depositional environment similar to the environment of deposition of stromatolitic limestone and evaporite facies in his study on Dam Fm. The presence of clay mineral palygorskite indicates recycled sediments in the basin that provided time for its growth (Shadfan and Mashhady 1985). The sandstone dominantly has a syn-sedimentary structure probably induced by tectonics, which also emphasizes the importance of tectonics at the time of Dam Fm as is seen in outcrop 3 (Fig. 9).

The occurrence of rhizoconcretions in the sequence (Fig. 8a, b, e) reflects exposure and subaerial substrate at the time of deposition. The surfaces along with rhizoconcretions or root traces occur were formed during low sea levels or exposure. Robust and continuous northwest Shamal winds frequently produce numerous metres of elevated waves during the June-August times in summer (Barth 2001). These waves can be considered as a tool for the enormous supply of sea with plentiful siliciclastic content, combined with carbonate deposition. The reworking of the beach sands and coastal dunes in the seashore setting are the other mechanisms that might have contributed to the influx of clastic materials into the carbonate dominated setting (Wilson 1975). The up-dip sections (northwest) of Dam Fm, especially the outcrops 4 and 5 (Fig. 3), have more sand dominated facies than the down-dip sections like outcrops 1, 2, and 3 (Ali and Abdullatif 2015). This is illustrated by up-dip exposures of the Hofuf siliciclastic units on the Lidam Escarpment (northwest of the outcrops), while broad cross-bedded eolian dune sands (Powers et al. 1966). The scarcity of fossils in the shaley calcareous sandstone specifies deposition under high-energy settings and hypersaline conditions. These clean sand sheets might have formed as eolian sand sheets and interdune sheets in a semi-arid, low vegetation coastal plain.

Parent sediments of channelized sandstone facies may have formed on the coastal terrace by introducing quartz via wind, ephemeral flooding, and longshore transportation (Alsharhan and Kendall 2003). The deposition of channelized sandstone facies, the near-shore setting indicates down-dip transition of the sands into shallow marine carbonates in the Dam Fm. (Fig. 2). There is a possibility of dissolution of some shells that were part of this facies that allowed later dissolution by meteoric waters and preserving it in the form of calcareous cement in the facies.

\section{Lagoonal to backshoal setting}

The subsidence continued in the area, and it was subjected to lagoonal or backshoal conditions leading to the deposition of foraminiferal mollusca pack-grainstone (Fig. 4c, e). The grain type shows control of larger foraminifera, gastropods, miliolids, and bivalves, with some micritized intraclasts and allochems in the facies (Fig. 5e, f), indicating a backshoal to lagoonal setting. The lack of algal fragments, textularids, open-marine fauna is observed. This facies presents the most diverse foraminiferal assemblage which includes larger foraminifera as well as miliolids (Triloculina, Quinqueloculina), followed by Cornuspira, Cibicides, Coscinospira, Elphidium, Peneroplis, and Operculina (Chan et al. 2017). Diversity of foraminifera, sedimentary structures, and grain size indicates lagoonal setting over the fair-weather wave base.

Foraminiferal mollusc packstone to grainstone facies is capped with carbonate shoal oolitic grainstone facies (Fig. 6f); grey-green quartz-bearing mudrock overlies the shoal deposited oolitic grainstone facies and represents rapidly changing depositional conditions. Mudcracks would indicate intertidal deposition and exposure. The thin layers indicate a mixed mud-silt tidal flat blanket after the exposure of the setting. This facies was deposited under quiet water with an arid climate, high oxygen levels, hypersaline, shallow lagoonal conditions, as demonstrated by the occurrence of bioturbations and lack of fossils. Deposition in shallow water is suggested with sedimentary structures indicating a period of exposure and reworking (Reineck and Singh 1980). These mudrocks probably were deposited in a depleted oxygen environment in a shallow lagoonal setting.

The depositional area was exposed that allowed the percolation of meteoric water. The mixing zone diagenesis could have contributed to the formation of karst in Dam Fm. (Fig. 4c). The occurrence of karst in this formation has been identified from various locations in Eastern Province, for example, cement quarry south of Scribners Canyon (AlSayari and Zötl 2012). During middle Burdigalian, the first karstification could have taken place at an early phase, for example, following the marine regression of early Miocene. The limestone of the Dam Fm. had to be elevated above sea level in this case (Al-Sayari and Zötl 2012).

In a nutshell, the Dam Fm. was formed in a mixed siliciclastic-carbonate environment, see Fig. 2. The Al-Lidam area remained under continuous sedimentation, the depositional setting shifts from carbonate to clastic dominated conditions until the termination of sedimentation. The depositional thickness was controlled by relative sea-level fluctuations that are accentuated by tectonic conditions and are reflected in facies, grain types, and geometries. In short, we can conclude that the Dam Fm of Al-Lidam area started evolving around 22-21 Ma (early Burdigalian, age from Chan et al. 2017) with breaks in carbonate sedimentation that allowed the deposition of sandstone and mudrocks. As discussed in the next section, facies, sedimentary 


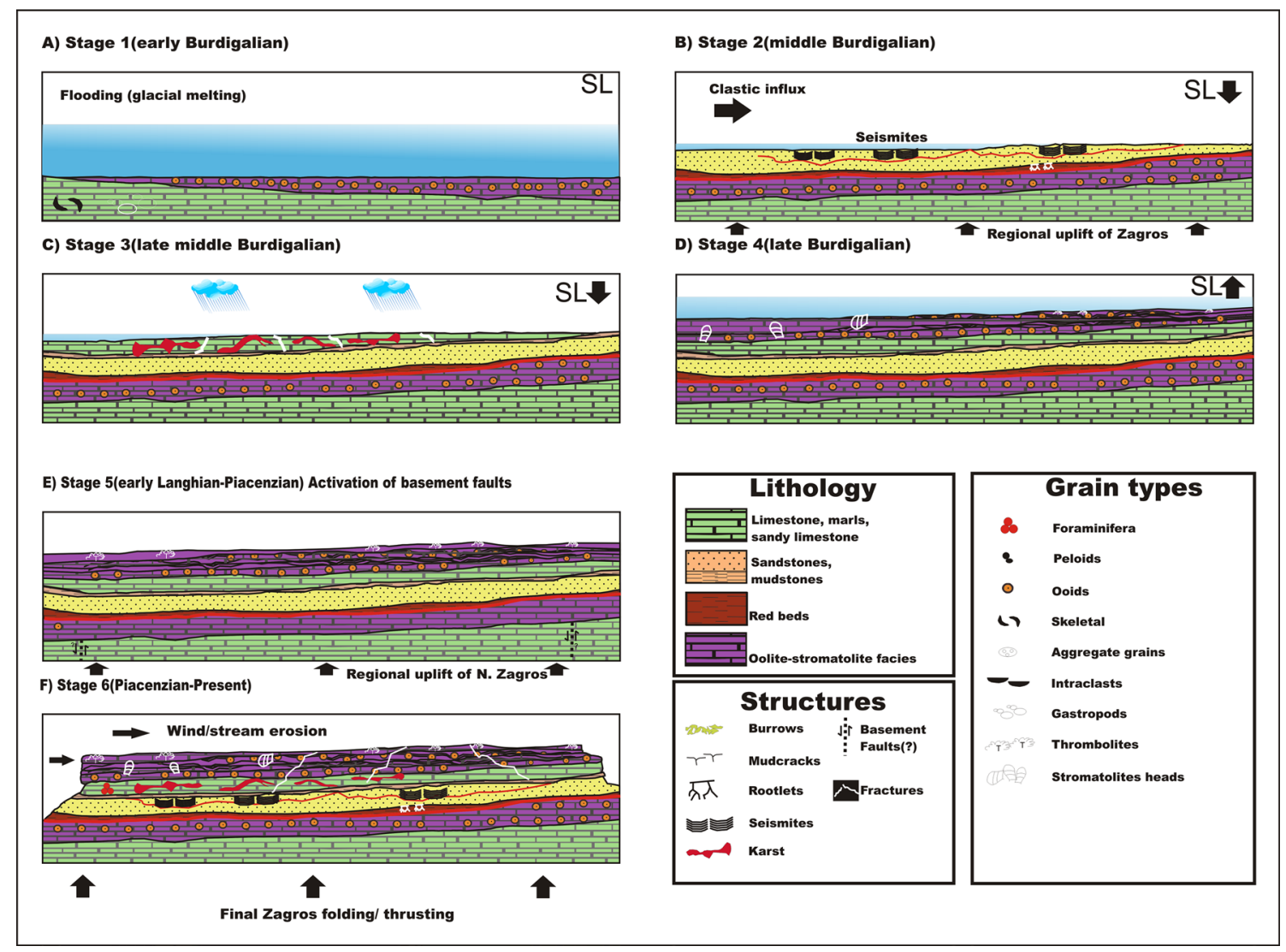

Fig. 10 Conceptual outcrop analogue model of Dam Fm. with deposition of carbonate-siliciclastic facies, with the formation of megafractures, activation of basement faults, uplift and subsidence. The tectonics was the main governing force along with the relative position of sea level, controlled the deposition in the area

on an outcrop, facies, and thin section data. Irtem (1986) studied the stromatolite growth in the Dam Fm., indicating that the unit was deposited in a tidal flat environment. Alkhaldi (2009) proposed that the Dam Fm. is a composite siliciclastic-carbonate sequence deposited in tidal flat, shallow lagoon, and near-shore shelf. Bashri et al. (2017) proposed estuarine and tidal flat depositional settings for siliciclastic and carbonate facies, respectively. However, studies by Chan et al. (2017) proposed the Burdigalian age based on the foraminifera recovered from the carbonate facies of Dam Fm. with depositional environment ranging from supratidal to subtidal conditions. Porosity model proposed by Abdelkarim et al. (2019) mentioned the continuity of facies in NW-SE and discontinuity in NE-SW direction, facies based on outcrop 3 .

This study reflects the very first attempt at characterizing and conceptually modelling the growth stages of the Dam Fm. based on the outcrop, field high-resolution data, facies types, architecture, and thin section data (Fig. 10). In Saudi Arabia, Zagros compression resulted in the inversion and activation of some of the basement faults and structures (Wender et al. 1998). study area starting from Burdigalian to present were based 


\section{Stage 1 (early Burdigalian)}

Due to glacio-eustacy adjustments with a response to Antarctic ice volume change, the sea level in the Al-Lidam area rose after the deposition of non-marine Hadrukh Fm. (Mitrovica and Milne 2003). The subsidence in the distal basin resulted from back-bulge basin creation that also played its role in the deposition of carbonate facies of Dam Fm. (Fig. 10a). These conditions favoured the deposition of gastropod grainstone facies, followed by an oolitic grainstone sheet in the area.

\section{Stage 2 (middle Burdigalian)}

During a regional uplift in the Zagros, the area became destabilized and changed into a clastic environment, where most of the sands were moved by Shamal winds, just like in the present-day Arabian Gulf. The rhizocretions or root traces that are present in the lower part of these sandstone facies also confirm the subaerial exposure (Fig. 10b). The presence of syn-depositional deformation structures or seismites in the clastic facies and is visible in outcrops 1,2 , and 3 indicated that the basin tectonically active in Middle Burdigalian (Fig. 9).

\section{Stage 3 (late middle Burdigalian)}

The relative dropping of sea level could have given the chance for the percolation of meteoric fluids in the mixing zone (Fig. 10c). This likely led to mixing zone diagenesis which resulted in the formation of karst-related features (Fig. 4c) and the development of secondary porosity due to grain dissolution (Fig. 5e). Karstification has been reported from Dam Fm. in several surface quarries for cement (Al-Sayari and Zötl 2012). The regional time equivalents, e.g. Jeribe Fm. and Fatha Fm from Iraq and Asmari Fm. (Jassim et al. 1997; Al-Jawad et al. 2020) from Iran karst-related phenomenon is reported (Mohammadi et al. 2007). This was also the time of the monsoon system in the Arabian Sea and the adjacent areas (Tripathi et al. 2017; Ge et al. 2019).

\section{Stage 4 (late Burdigalian)}

During this stage, the accommodation space was diminished and that gave rise to the development of a muddy lagoon with a reduced environment (Fig. 10d). A relatively aggressive environment came into existence as a result and led to the development of a short event of microbialites and the disappearance of metazoans. Later, facies types of stromatolite boundstone, microbialite intraclastic packstone, microbial ooid grainstone, and thrombolitic boundstone were controlled by minor alterations of sea level. Microbialite facies possibly be traced into all the five outcrops (Fig. 2).

\section{Stage 5 (early Langhian-Piacenzian)}

The study area was uplifted due to the activation of basement faults (Fig. 10e) that followed the ongoing collision of Arabian and Eurasian convergence in Zagros. The Hofuf Fm. and upper parts of Dam Fm. widely present in Eastern Saudi Arabia are erosionally truncated in the study area. According to some authors (Jahani et al., 2009), it is the time of uplift in the Northern Zagros as well as the regional folds development.

\section{Stage 6 (Piacenzian-Present)}

The fast accretion of the Zagros occurred in the duration of $5 \mathrm{Ma}$, which resulted in rapid erosion rates. The strata in the distal Zagros basin was uplifted and resulted in rapid erosion and denudation by seasonal streams, sand drift, and wind that resulted in the present topography in the Al-Lidam area. The sand drift is a wind regime (uni-modal) that mainly followed the path from North to South in the Eastern Arabian Platform (Barth 2001). Final Zagros folding/thrusting and weathering by wind or seasonal streams resulted in the formation of present landforms (Ali et al. 2016b). This sand drift picks sand from the North of the Eastern Province and deposit in the south. Hence, the lower parts of the outcrops in the Al-Lidam area are covered in Holocene sand deposits (Fig. 10f).

\section{Conclusions}

It is definitive from the substantiation provided here that facies, deposition, architecture, and heterogeneity in Dam Fm. were robustly controlled by relative sea-level alterations that were accentuated by tectonics. Tectonics in the Zagros provided the back-bulge and controlled the basement faulting. The Dam Fm. in Al-Lidam is divided into twelve facies that are deposited in three episodes, where carbonates are interlayered by siliciclastic facies. The tectonics provided the accommodation space by subsidence and later by uplift that is reflected in karstification and paleosols. The following highlights the major findings of this study are:

(1) Glacial flooding (early Burdigalian) and the subsidence played an important role in the distal back-bulge basin to deposition carbonate facies of Dam Fm. Clastic influx during the (middle Burdigalian) mainly provided by the active tectonics in the area. That is evident by the 
presence of syn-depositional deformation structures or seismites in the clastic facies.

(2) The relative lowering of sea level in late middle Burdigalian might have allowed the percolation of meteoric fluids in the mixing zone diagenesis. That could have resulted in the formation of karst-related features as well. The deposition of the siliciclastics was driven by lowered sea levels, and moderately humid to an arid climate.

(3) Thrusting, uplift, and basement faulting all played their role along with the rapid erosion rates in the present topography of Al-Lidam area.

(4) Rising sea levels pushed the siliciclastics up-dip allowing mixed siliciclastics and carbonates to deposit from down-dip, under semi-arid climate, and hypersaline environment.

(5) The deposition starts as a carbonate ramp, with the lowering of sea level the siliciclastic covered the carbonates. Afterwards, as the accommodation space is diminished that resulted in a restricted setting for the growth of metazoans and the deposition of microbialites.

(6) The thickness and distribution of facies are mainly controlled by glacio-eustacy cycles and relative sea-level changes punctuated by tectonics (e.g. basement faulting)

(7) The Dam Fm. can be used as an analogue for subsurface reservoirs in the Northern Arabian Gulf for understanding reservoir architecture and heterogeneity. The results presented here are promising for Dam Fm. to be a future reservoir in the Arabian Gulf, although facies changes and subsurface conditions can have minor modifications. Hence, it is recommended that numerical model may be generated for better understanding of Dam Fm. as a potential reservoir.

Acknowledgements The authors would like to appreciate College of Petroleum and Geosciences, KFUPM, for providing help during fieldwork. We thank Professor Turgay Ertekin (Editor-in-Chief, Journal of Petroleum Exploration and Production Technology), and two anonymous reviewer who provided critical helpful comments and suggestions to our manuscript; nevertheless, we take full responsibility for our interpretation. The authors are much obliged to the Springer proofreading team for handling the work, sending reviews, and preparing the proof.

Author's contributions Syed Haroon Ali was involved in writingoriginal draft, conceptualization, data curation, formal analysis, investigation, methodology, visualization, writing - review \& editing. Osman M. Abdullatif helped in supervision, writing-original draft, validation, writing-review \& editing. Lamidi O. Babalola contributed to writing — original draft, validation, writing — review \& editing. Fawwaz M. Alkhaldi was involved in writing-original draft, validation, writing — review \& editing. Yasir Bashir helped in writing — original draft, validation, writing - review \& editing. S.M. Talha Qadri contributed to writing — original draft, validation, writing—review \& editing. Ali Wahid was involved in writing - original draft, validation, writingreview \& editing. All authors read and approved the final manuscript.

Funding This research did not receive any specific grant from funding agencies in the public, commercial, or not-for-profit sectors.

Data availability The data used in this manuscript can be obtained from the corresponding author upon reasonable request.

\section{Declarations}

Conflict of interest The authors declare that they have no conflict of interest.

Ethics approval Not applicable.

Consent to participate Not applicable.

Consent for publication Not applicable.

Open Access This article is licensed under a Creative Commons Attribution 4.0 International License, which permits use, sharing, adaptation, distribution and reproduction in any medium or format, as long as you give appropriate credit to the original author(s) and the source, provide a link to the Creative Commons licence, and indicate if changes were made. The images or other third party material in this article are included in the article's Creative Commons licence, unless indicated otherwise in a credit line to the material. If material is not included in the article's Creative Commons licence and your intended use is not permitted by statutory regulation or exceeds the permitted use, you will need to obtain permission directly from the copyright holder. To view a copy of this licence, visit http://creativecommons.org/licenses/by/4.0/.

\section{References}

Abdelkarim AA, Abdullatif OM, Babalola LO, Makkawi MH, Yassin MA (2019) High-resolution lithofacies and porosity modeling of the mixed siliciclastic-carbonate deposits of the Burdigalian Dam Formation, Eastern Saudi Arabia. Int J Earth Sci 108(1):155-172

Abreu VS, Anderson JB (1998) Glacial eustasy during the Cenozoic: sequence stratigraphic implications. AAPG Bull 82(7):1385-1400

Ajirlu MS, Moazzen M, Hajialioghli R (2016) Tectonic evolution of the Zagros Orogen in the realm of the Neotethys between Central Iran and Arabian Plates: an ophiolite perspective. Cent Eur Geol 59(1-4):1-27

Alavi M (2007) Structures of the Zagros fold-thrust belt in Iran. Am J Sci 307(9):1064-1095

Ali S, Al-Umary F, Sarkawt S, Al-Ansari N, Knutsson S (2016a) Geomorphology of Garmiyan Area using GIS technique, Kurdistan Region, Iraq. J Earth Sci Geotech Eng 6(1):63-87

Ali SH (2015a) High-resolution stratigraphic architecture and sedimentological heterogeneity within the Miocene dam formation, Eastern Province, eastern Saudi Arabia Masters Thesis, King Fahd University of Petroleum and Minerals, Saudi Arabia

Ali SH (2020a) Sedimentology and diagenesis of miocene carbonate buildups, Offshore, Sarawak, Malaysia, Ph.D. Thesis (Unpublished). 
Ali SH, Abdullatif O, (2015b) High-resolution stratigraphic architecture and sedimentological heterogeneity within the Miocene Dam Formation. In: 11th International conference for geosciences, 12-14 May, 2015, King Saud University, Riyadh, Saudi Arabia (Abstract Book)

Ali SH, Abdullatif O, Abioui M, Bashir Y, Wahid A, Yasin Q (2021) Dolomitization and paleoenvironment of deposition of the Lower and Middle Rus Formation (Early Eocene, Dammam Dome, Eastern Saudi Arabia). J Sediment Environ 2:10

Ali SH, Abdullatif O, Babalola LO (2016b) Sedimentary facies, sequence stratigraphy of mixed carbonate-siliciclastic sediments (early middle Miocene dam formation, eastern Saudi Arabia). In: International conference and exhibition, Barcelona, Spain, 3-6 April 2016, pp 294-294. Society of Exploration Geophysicists and American Association of Petroleum Geologists (Abstract Book)

Ali SH, Poppelreiter MC Saw BB, Shah MM, Bashir Y (2021b) Microfacies, diagenesis and secondary porosity of a Miocene reefal platform of Central Luconia, Malaysia, Carbonates and Evaporites (Accepted)

Al-Jawad SN, Abd Ahmed M, Saleh AH (2020) Integrated reservoir characterization and quality analysis of the carbonate rock types, case study, southern Iraq. J Petrol Explor Prod Technol 10(8):3157-3177

Alkhaldi FM (2009) Controls on hierarchy of miocene buildups within a high-resolution cycle stratigraphic framework of Dam Formation, Lidam Area, Saudi Arabia (Masters Thesis, King Fahd University of Petroleum and Minerals).

Alkhaldi FM, Read JF and Tawil A (2014) Mixed carbonate-siliciclastic sequence development on a distal fore-land during miocene glaciation, Eastern Saudi Arabia. In: International conference and exhibition, Istanbul, Turkey

Al-Sayari SS, Zötl JG (eds) (2012) Quaternary period in Saudi Arabia: 1: sedimentological, hydrogeological, hydrochemical, geomorphological, and climatological investigations in central and eastern Saudi Arabia. Springer, Berlin

Alsharhan AS (1993) Facies and sedimentary environment of the Permian carbonates (Khuff Formation) in the United Arab Emirates. Sed Geol 84(1-4):89-99

Alsharhan AS, Kendall CS (2003) Holocene coastal carbonates and evaporites of the southern Arabian Gulf and their ancient analogues. Earth Sci Rev 61(3-4):191-243

Alsharhan AS, Nairn AE (1995) Tertiary of the Arabian Gulf: sedimentology and hydrocarbon potential. Palaeogeogr Palaeoclimatol Palaeoecol 114(2-4):369-384

Anan TI (2014) Facies analysis and sequence stratigraphy of the Cenomanian-Turonian mixed siliciclastic-carbonate sediments in west Sinai. Egypt Sediment Geol 307:34-46

Armella C (1994) Thrombolitic-stromatolitic cycles of the CambroOrdovician boundary sequence, Precordillera Oriental Basin, western Argentina. In: Phanerozoic stromatolites II, pp 421441. Springer, Dordrecht

Asprion U, Aigner T (1999) Towards realistic aquifer models: threedimensional georadar surveys of Quaternary gravel deltas (Singen Basin, SW Germany). Sed Geol 129(3-4):281-297

Awais M, Ullah F, Khan N, Ghani M, Siyar SM, Wadood B, Mukhtiar A (2019) Investigation of reservoir characteristics, depositional setting and T-R sequences of the Lockhart Limestone of Meyal Oil field, Pakistan: a petrophysical approach. J Petrol Explor Prod Technol 9(4):2511-2530

Barth HJ (2001) Characteristics of the wind regime north of Jubail, Saudi Arabia, based on high-resolution wind data. J Arid Environ 47(3):387-402

Bashri M, Abdullatif O, Salih M (2017) Sedimentology and facies analysis of Miocene mixed siliciclastic-carbonate deposits of the Dam Formation in Al Lidam area, eastern Saudi Arabia. Arab J Geosci 10(21):472

Bi D, Zhai S, Zhang D, Xiu C, Liu X, Liu X, Jiang L, Zhang A (2019) Geochemical characteristics of the trace and rare earth elements in reef carbonates from the Xisha Islands (South China Sea): implications for sediment provenance and paleoenvironment. J Ocean Univ China 18(6):1291-1301

Bosence D (2005) A genetic classification of carbonate platforms based on their basinal and tectonic settings in the Cenozoic. Sed Geol 175(1-4):49-72

Botha GA, Hughes JC (1992) Pedogenic palygorskite and dolomite in a late Neogene sedimentary succession, northwestern Transvaal. South Africa Geoderma 53(1-2):139-154

Boulton SJ, Robertson AH (2007) The Miocene of the Hatay area, S Turkey: transition from the Arabian passive margin to an underfilled foreland basin related to the closure of the Southern Neotethys Ocean. Sed Geol 198(1-2):93-124

Brachert TC (1992) Sequence stratigraphy and paleo-oceanography of an open-marine mixed carbonate/siliciclastic succession (Late Jurassic, Southern Germany). Facies 27(1):191-216

Brandano M (2014) Ronca S (2014) Depositional processes of the mixed carbonate-siliciclastic rhodolith beds of the Miocene Saint-Florent Basin, northern Corsica. Facies 60(1):73-90

Bressan GS, Palma RM (2009) Trace fossils from the Lower-Middle Jurassic Bardas Blancas Formation, Neuquén Basin, Mendoza Province, Argentina. Acta Geologica Polonica 59(2):201-220

Bretis B, Grasemann B, Conradi F (2012) An active fault zone in the western Kopeh Dagh (Iran). Austrian J Earth Sci 105(3):95-107

Carlucci JR, Westrop SR, Brett CE, Burkhalter R (2014) Facies architecture and sequence stratigraphy of the Ordovician Bromide Formation (Oklahoma): a new perspective on a mixed carbonatesiliciclastic ramp. Facies 60(4):987-1012

Chan SA, Kaminski MA, Al-Ramadan K, Babalola LO (2017) Foraminiferal biofacies and depositional environments of the Burdigalian mixed carbonate and siliciclastic Dam Formation, Al-Lidam area, Eastern Province of Saudi Arabia. Palaeogeogr Palaeoclimatol Palaeoecol 469:122-137

Cornacchia I, Munnecke A, Brandano M (2020) The potential of carbonate ramps to record C-isotope shifts: insights from the upper Miocene of the Central Mediterranean area. Lethaia 54:73-89

Dantas MV, Holz M (2020) High-resolution sequence stratigraphy of a cretaceous mixed siliciclastic-carbonate platform succession of the Sergipe-Alagoas Basin, NE Brazil. Facies 66:4

Dolan JF (1989) Eustatic and tectonic controls on deposition of hybrid siliciclastic/carbonate basinal cycles: discussion with examples1. AAPG Bull 73(10):1233-1246

Dunham RJ (1962) Classification of carbonate rocks according to depositional textures. In: M 1: Classification of carbonate rocks-a symposium, Special Publication Type: Memoir, pp 108-122

Eltom HA, Saraih NA, Esteva OG, Kusuma L, Ahmed S, Yassin MA (2020) Three-dimensional modeling and fluid flow simulation for the quantitative description of permeability anisotropy in tidal flat carbonate. Energies 13(21):5557

El-Yamani MS, Al-Ramadan K, Munnecke A, Cantrell D, Abdulghani W, Reub L (2018) Microfacies, depositional environments and meter-scale cycles of the middle Jurassic Tuwaiq Mountain Formation, Central Saudi Arabia. J Afr Earth Sc 145:80-101

Embry AF, Klovan JE (1972) Absolute water depth limits of Late Devonian paleoecological zones. Geol Rundsch 61(2):672-686

Enge HD, Buckley SJ, Rotevatn A, Howell JA (2007) From outcrop to reservoir simulation model: workflow and procedures. Geosphere 3(6):469-490

Enos P, Perkins RD (1977) Quaternary sedimentation in south Florida. Geol Soc Am 9:61 
Fabuel-Perez I, Hodgetts D, Redfern J (2009) A new approach for outcrop characterization and geostatistical analysis of a low-sinuosity fluvial-dominated succession using digital outcrop models: Upper Triassic Oukaimeden Sandstone Formation, central High Atlas, Morocco. AAPG Bull 93(6):795-827

Farzipour-Saein A, Yassaghi A, Sherkati S, Koyi H (2009) Basin evolution of the Lurestan region in the Zagros fold-and-thrust belt. Iran J Petrol Geol 32(1):5-19

Flügel E (2010) Microfacies of carbonate rocks: analysis, interpretation and application. Springer, Berlin

Frey RW, Howard JD (1986) Mesotidal estuarine sequences; a perspective from the Georgia Bight. J Sediment Res 56(6):911-924

Ge Q, Xu D, Ye L, Yang K, Yao Z (2019) Linking monsoon activity with river-derived sediments deposition in the Northern South China Sea. J Ocean Univ China 18(5):1098-1104

Ghasemi A, Talbot CJ (2006) A new tectonic scenario for the SanandajSirjan Zone (Iran). J Asian Earth Sci 26(6):683-693

Ghon G, Rankey EC, Baechle GT, Schlaich M, Ali SH, Mokhtar S, Poppelreiter MC (2018) Carbonate reservoir characterisation of an isolated platform integrating sequence stratigraphy and rock physics in Central Luconia. In: 80th EAGE conference and exhibition, Vol 2018, No 1, pp 1-5. European Association of Geoscientists \& Engineers

Gomez F, Nemer T, Tabet C, Khawlie M, Meghraoui M, Barazangi M (2007) Strain partitioning of active transpression 715 within the Lebanese restraining bend of the Dead Sea Fault (Lebanon and SW Syria). Geolog Soc 290(1):285-303

Grammer GM, Harris PM, Eberli GP (2004) Integration of outcrop and modern analogs in reservoir modeling: an overview with examples from the Bahamas

Guerrera F, Martin-Algarra A, Perrone V (1993) Late OligoceneMiocene syn-/-late-orogenic successions in western and central Mediterranean chains from the Betic Cordillera to the southern Apennines. Terra Nova 5(6):525-544

Hallock P, Glenn EC (1986) Large foraminifera; a tool for paleoenvironmental analysis of Cenozoic carbonate depositional facies. Palaios 1(1):55-64

He J, Wang H, Zhang C, Yang X, Shangguan Y, Zhao R, Gong Y, Wu Z (2019) A comprehensive analysis of the sedimentology, petrography, diagenesis and reservoir quality of sandstones from the Oligocene Xiaganchaigou (E 3) Formation in the Lengdong area, Qaidam Basin, China. J Pet Explor Prod Technol 9(2):953-969

Hempton MR (1987) Constraints on Arabian plate motion and extensional history of the Red Sea. Tectonics 6(6):687-705

Hoffman P (1976) Stromatolite morphogenesis in Shark Bay, Western Australia. In: Developments in sedimentology, Vol 20, pp 261-271. Elsevier

Irtem O (1986) Miocene tidal flat stromatolites of the Dam Formation, Saudi Arabia. Arab J Sci Eng 12(2):145-153

Islam MA, Yunsi M, Qadri SMT, Shalaby MR, Haque AKME (2021) Three-dimensional structural and petrophysical modelling for reservoir characterization of the Mangahewa Formation, Pohokura Gas Condensate Field Taranaki Basin, New Zealand. Nat Resour Res 30:371-394

Jahani S, Callot JP, Letouzey J, de Frizon LD (2009) The eastern termination of the Zagros Fold-and-Thrust Belt, Iran: structures, evolution, and relationships between salt plugs, folding, and faulting. Tectonics 28(6): 170

James NP, Bone Y, Kyser TK, Dix GR, Collins LB (2004) The importance of changing oceanography in controlling late Quaternary carbonate sedimentation on a high-energy, tropical, oceanic ramp: North-Western Australia. Sedimentology 51(6):1179-1205

Jassim SZ, Jibril AS, Numan NM (1997) Gypsum karstification in the middle Miocene Fatha Formation, Mosul area, Northern Iraq. Geomorphology 18(2):137-149
Johnson C (2008) Phanerozoic plate reconstructions of the Middle East: insights into the context of Arabian tectonics and sedimentation. In: Abu Dhabi international petroleum exhibition and conference, 3-6 November, Abu Dhabi, UAE

Kamran M, Frontalini F, Xi DP, Mirza K, Jafarian A, Latif K, Ali F, Kashif M, Fawad N, Shafi M, Wan XQ (2020) Larger benthic foraminiferal assemblages and their response to Middle Eocene Climate Optimum in the Kohat Basin (Pakistan, eastern Tethys). Palaeoworld

Khadivi S (2010) Tectonic evolution and growth of the Zagros Mountain Belt (Fars, Iran): constraints from magnetostratigraphy, sedimentology, and low-temperature thermochronometry (Doctoral dissertation).

Klappa CF (1980) Rhizoliths in terrestrial carbonates: classification, recognition, genesis, and significance. Sedimentology 27(6):613-629

Koshnaw RI, Horton BK, Stockli DF, Barber DE, Tamar-Agha MY, Kendall JJ (2017) Neogene shortening and exhumation of the Zagros fold-thrust belt and foreland basin in the Kurdistan region of northern Iraq. Tectonophysics 694:332-355

Kumar N, Sanders JE (1976) Characteristics of shoreface storm deposits; modern and ancient examples. J Sediment Res 46(1):145-162

Longacre SA, Ginger EP (1988) Evolution of the lower cretaceous Ratawi oolite reservoir, Wafra field, Kuwait-Saudi Arabia partitioned neutral zone

Loreau JP, Purser BH (1973) Distribution and ultrastructure of Holocene ooids in the Persian Gulf. In: The Persian Gulf, pp 279-328. Springer, Berlin

Mitrovica JX, Milne GA (2003) On post-glacial sea level: I. General theory. Geophys J Int 154(2):253-267

Mohammadi E (2020) Sedimentary facies and paleoenvironmental interpretation of the Oligocene larger-benthic-foraminiferadominated Qom Formation in the northeastern margin of the Tethyan Seaway. Palaeoworld

Mohammadi Z, Raeisi E, Bakalowicz M (2007) Evidence of karst from behavior of the Asmari limestone aquifer at the Khersan 3 Dam site, southern Iran. Hydrol Sci J 52(1):206-220

Moore CH (1989) Carbonate diagenesis and porosity. Elsevier, Oxford

Mouthereau F, Lacombe O, Vergés J (2012) Building the Zagros collisional orogen: timing, strain distribution, and the dynamics of Arabia/Eurasia plate convergence. Tectonophysics 532:27-60

Mukhopadhyay A, Al-Sulaimi J, Al-Awadi E, Al-Ruwaih F (1996) An overview of the Tertiary geology and hydrogeology of the northern part of the Arabian Gulf region with special reference to Kuwait. Earth Sci Rev 40(3-4):259-295

Palma RM, Forte GL, Medhli M, Piethé RD (2005) High-frequency subtidal-peritidal cycles of the Callovian Calabozo Formation (Neuquén Basin, Western Argentina): a preliminary approach. Geol Acta 3(2):119-132

Patton TL, O'connor SJ (1988) Cretaceous Flexural History of Northern Oman Mountain Foredeep, United Arab Emirates1. AAPG Bull 72(7):797-809

Pirouz M, Simpson G, Bahroudi A, Azhdari A (2011) Neogene sediments and modern depositional environments of the Zagros foreland basin system. Geol Mag 148(5-6):838-853

Platt NH (1989) Lacustrine carbonates and pedogenesis: sedimentology and origin of palustrine deposits from the Early Cretaceous Rupelo Formation, W Cameros Basin. N Spain Sedimentol 36(4):665-684

Powers RW, Ramirez LF, Redmond CD, Elberg EL (1966) Geology of the Arabian peninsula. In: Geological survey professional paper, vol 560, pp D1-D147

Pratt BR (1982) Stromatolitic framework of carbonate mud-mounds. J Sediment Res 52(4):1203-1227
(2) مدينة الملك عبدالعزيز KACST 
Pringle JK, Howell JA, Hodgetts D, Westerman AR, Hodgson DM (2006) Virtual outcrop models of petroleum reservoir analogues: a review of the current state-of-the-art. First Break 24(3):50

Qadri SMT, Islam MA, Shalaby MR (2017) Seismic Interpretation and structural modelling of Kupe Field, Taranaki Basin, New Zealand. Arab J Geosci 10:295

Qadri SMT, Islam MA, Shalaby MR (2019) Three-dimensional petrophysical modelling and volumetric analysis to model the reservoir potential of the Kupe Field, Taranaki Basin, New Zealand. Nat Resour Res 28(2):369-392

Qadri SMT, Islam MA, Shalaby MR (2019) Application of well log analysis to estimate the petrophysical parameters and evaluate the reservoir quality of the Lower Goru Formation, Lower Indus Basin, Pakistan. Geomech Geophys Geo-Energy Geo-Resour 5:271-288

Qadri SMT, Islam MA, Shalaby MR, Ali SH (2020) Integration of 1D and $3 \mathrm{D}$ modeling schemes to establish the Farewell Formation as a self-sourced reservoir in Kupe Field, Taranaki Basin, New Zealand. Front Earth Sci 3:1-18

Qadri SMT, Islam MA, Shalaby MR, El-Aal A (2021) Reservoir quality evaluation of the Farewell sandstone by integrating sedimentological and well log analysis in the Kupe South Field, Taranaki Basin, New Zealand. J Pet Explor Prod Technol 11:11-31

Rankey EC, Schlaich M, Mokhtar S, Ghon G, Ali SH, Poppelreiter M (2019) Seismic architecture of a Miocene isolated carbonate platform and associated off-platform strata (Central Luconia Province, offshore Malaysia). Mar Pet Geol 102:477-495

Redfern J, Shannon PM, Williams BP, Tyrrell S, Leleu S, Perez IF, Baudon C, Štolfová K, Hodgetts D, Van Lanen X, Speksnijder A, Haughton PDW, Daly JS (2010) An integrated study of PermoTriassic basins along the North Atlantic passive margin: implication for future exploration. In: Geological society, London, Petroleum Geology Conference series, vol 7, no 1, pp 921-936. Geological Society of London

Reilinger R, McClusky S, Vernant P, Lawrence S, Ergintav S, Cakmak R, Ozener H, Kadirov F, Guliev I, Stepanyan R, Nadariya M (2006) GPS constraints on continental deformation in the AfricaArabia-Eurasia continental collision zone and implications for the dynamics of plate interactions. J Geophys Res Solid Earth 111(B5):57

Reineck HE, Singh IB (1980) Tidal flats. In: Depositional sedimentary environments, pp 355-372. Springer, Berlin

Ring U (2014) The East African rift system. Austrian J Earth Sci 107(1):132-146

Roberts DG, Bally AW (2012) Carbonate dominated marine rifts. Reg Geol Tecton 1:105

Sanders D, Pons JM (2001) Stratigraphic architecture of a Santonian mixed siliciclastic-carbonate succession (Catalonian Pyrenees, Spain). Facies 44(1):105-135

Saner S, Al-Hinai K, Perincek D (2005) Surface expressions of the Ghawar structure, Saudi Arabia. Mar Pet Geol 22(5):657-670

Saw BB, Poppelreiter M, Vintaned JAG, Ali SH (2017) Anatomy of an Isolated Carbonate Platform: Subis Limestone Outcrop, Early Miocene, Niah, Sarawak, Malaysia, NGC Conference, Malaysia (Abstract Book)

Saw BB, Schlaich M, Pöppelreiter MC, Ramkumar M, Lunt P, Vintaned JA, Ali SH (2019) Facies, depositional environments, and anatomy of the Subis build-up in Sarawak, Malaysia: implications on other Miocene isolated carbonate build-ups. Facies 65(3):28

Scholle PA, Bebout DG, Moore CH (eds) (1983) Carbonate depositional environments: AAPG Memoir 33. AAPG
Shadfan H, Mashhady AS (1985) Distribution of palygorskite in sediments and soils of eastern Saudi Arabia. Soil Sci Soc Am J 49(1):243-250

Sharland PR, Casey DM, Davies RB, Simmons MD, Sutcliffe OE (2004) Arabian plate sequence stratigraphy-revisions to SP2. GeoArabia 9(1):199-214

Stern RJ, Johnson P (2010) Continental lithosphere of the Arabian Plate: a geologic, petrologic, and geophysical synthesis. Earth Sci Rev 101(1-2):29-67

Tayyib MA (2007) Depositional Setting Impact on the Portland Cement Production Quality of the Dam Formation, Saudi Arabia. ProQuest. Master of Science Thesis, King Fahd University of Petroleum and Minerals

Tleel JW (1973) Surface geology of Dammam dome, eastern province, Saudi Arabia. AAPG Bull 57(3):558-576

Tripathi S, Tiwari M, Lee J, Khim BK, Expedition IO, Pandey DK, Clift PD, Kulhanek DK, Andò S, Bendle JA, Aharonovich S (2017) First evidence of denitrification vis-à-vis monsoon in the Arabian Sea since Late Miocene. Sci Rep 7:43056

Verwer K, Braaksma H, Kenter JA (2008) Acoustic properties of carbonates: effects of rock texture and implications for fluid substitution. Geophysics 73(2):B51-B65

Wagner CW, Van der Togt C (1973) Holocene sediment types and their distribution in the southern Persian Gulf. In: The Persian Gulf, pp 123-155. Springer, Berlin

Warrlich G, Bosence D, Waltham D, Wood C, Boylan A, Badenas B (2008) 3D stratigraphic forward modelling for analysis and prediction of carbonate platform stratigraphies in exploration and production. Mar Pet Geol 25(1):35-58

Weijermars R (1999) Surface geology, lithostratigraphy and Tertiary growth of the Dammam Dome, Saudi Arabia: a new field guide. GeoArabia 4(2):199-226

Wender LE, Bryant JW, Dickens MF, Neville AS, Al-Moqbel AM (1998) Paleozoic (Pre-Khuff Hydrocarbon Geology of the Ghawar Area, Eastern Saudi Arabia. Geoarabia 3(2):273-302

Wilson JL (1975) The lower carboniferous Waulsortian facies. In: Carbonate facies in geologic history, pp 148-168. Springer, New York

Wilson ME (2012) Equatorial carbonates: an earth systems approach. Sedimentology 59(1):1-31

Woods AD (2013) Microbial ooids and cortoids from the Lower Triassic (Spathian) Virgin Limestone, Nevada, USA: evidence for an Early Triassic microbial bloom in shallow depositional environments. Global Planet Change 105:91-101

Yang HQ, Shen JW, Yang HJ, Zhang LJ, Li M, Wang JP (2014) Mixed carbonate-clastic facies in the Eocene Kalatar Formation of the southwest Tarim Basin (NW China): tectonic and climatic controls. Facies 60(1):111-131

Zhang Y, Wang J, Munnecke A, Li Y (2015) Ramp morphology controlling the facies differentiation of a Late Ordovician reef complex at Bachu, Tarim Block, NW China. Lethaia 48(4):509-521

Ziegler AZ (2001) Late Permian to Holocene paleofacies evolution of the Arabian Plate and its hydrocarbon occurrences. GeoArabia 6(3):445-504

Publisher's note Springer Nature remains neutral with regard to jurisdictional claims in published maps and institutional affiliations. 